\title{
Are Foreign Migrants more Assimilated than Native Ones?
}

\author{
Riccardo Faini $\uparrow$ \\ (Università di Roma Tor Vergata, CEPR, and IZA) \\ Steinar Strom \\ (University of Oslo and Università di Torino) \\ Alessandra Venturini \\ (Università di Torino, IZA, FIERI, CHILD) \\ Claudia Villosio \\ (LABORatorio R. Revelli, Collegio Carlo Alberto)
}

\begin{abstract}
The paper compares the pattern of wage assimilation of foreigners with both native immigrants and local natives in Italy, a country with large internal and international migration. This comparison, not yet exploited, yields understanding of the role played by language and knowledge of social capital.

We use the administrative dataset on dependent employment (WHIP), to estimate a fixed effect model of the weekly wages of males aged 18-45 with controls for selection in return migration and unobserved heterogeneity.

The three groups of workers start their careers at the same wage level but, as experience increases, the wage profiles of foreigners and natives, both immigrants and locals, diverge. A positive selection in the returns prevails, so that the foreign workers with lower wages are the most likely to stay in Italy. Also an "ethnic" skill differential emerges and a negative status dependence for those entering at low wage level.
\end{abstract}

JEL code: J31, J61, C23

Keywords: Migration, Assimilation, Wage differential

Acknowledgments:

We thank David Card, Martin Ruhs, Herbert Brucker, Dan-Olof Rooth, Tommaso Frattini, Emilio Reyneri, and participants to the ESPE 2008, EALE 2008, IMISCOE and TOM conferences for helpful comments.

Corresponding author:

Alessandra Venturini

alessandra.venturini@unito.it 


\section{Introduction}

Italy is very well known for its long tradition of international and internal migration ${ }^{1}$ and less well known for its experience with immigration. Foreign migrants started to choose Italy as a destination country at the end of the 1970s, when after the first oil shock the Northern European countries adopted restrictive immigration policies which made it more difficult for foreigners to enter their labour markets. The inflows to Italy, and in general to the Southern European countries, thereafter became increasingly important, in 2007 reaching $6 \%$ of the population in Italy and Greece, $4 \%$ in Portugal and 12\% in Spain (OECD, 2009).

The political debate initially focused on the entrance of foreigners, on their potential competitive role on the labour market, ${ }^{2}$ and on the most suitable immigration policy to adopt.

This study aims at gaining better understanding of the assimilation pattern of foreign migrants in Italy by comparing foreign migrants with native workers, both native migrants and native locals (who work in the same area of birth). The comparison, which has never before been conducted in Italy or other countries, is very interesting because, unlike foreign migrants, native immigrants are supposed to know the language of the destination country, a feature which the empirical literature has shown to be very important for the assimilation profile. Moreover, native immigrants should also share some of the social rules that apply in the destination countries, so that they should not be disadvantaged relative to national local workers, or they should at least be less disadvantaged than foreign migrants.

However, anecdotal evidence on Italian native migrants, reported in novels, films and sociological research (for instance Fofi 1975 and Ascolani et al. 1974), presents a very different scenario where, especially during the 1960s and 1970s, southern native migrants in North Italy had great difficulties in being understood because they spoke different local dialects. Moreover, their behavior did not comply with the way of life in the industrial cities, ${ }^{3}$ so that they were discriminated against in their everyday lives, especially when renting accommodation, and perceived as foreigners. Employers when hiring do not know the worker's individual productivity but have greater difficulties in evaluating immigrants, both native and foreign, with the consequence that native immigrants and foreigners may be more similar in their initial wage profiles.

Our aim is therefore to test whether foreign immigrants (foreigners born abroad and working in the region) perform differently from local workers (born and working in the same area), immigrant natives (born in an area different from the working one), thereby contribute to better understanding of the role of language and social norms in economic assimilation.

\section{Brief historical summary}

During the 1980s, as a new country of immigration, Italy was first exposed to immigration from neighbouring areas (North Africa) and from Asia (mainly Filipinos) and Latin America. With the fall of the Berlin Wall, inflows began from the Eastern European countries. Initially, the migrants came from the very close Albania, but they later arrived from the more distant Romania and Moldova,

\footnotetext{
${ }^{1}$ For a survey see Del Boca and Venturini 2005.

${ }^{2}$ The available empirical research shows that in general foreigners do not compete with natives in the Italian labour market (Gavosto et al. 1999, Venturini and Villosio 2006).

${ }^{3}$ They reputedly grew tomatoes, basil and parsley in their bath tubs.
} 
attracted by the similarity of language, but also from as far away as Ukraine (See Figure 1).

In many cases, their entry took place illegally, and their regular position has been the result of the many amnesties granted by the Italian government. To become legal, migrants should have a regular job offer, and to obtain one, they have usually worked illegally for at least a couple of years. The number of regular permits decided by the government has always been insufficient to satisfy the supply of immigrants but also the national demand for them. Illegal entry was used as a first step in a process of legal entrance into the destination country. The repetition of amnesties - a policy however shared with the other Southern European countries - has created the expectation of further sanatoria and augmented the difficulties in controlling the migratory phenomenon (see on this Venturini 2004: ch. 5). The strong reaction of the native population against larger legal and official inflows has been accompanied by the belief that it is impossible to control the country's borders. The information set out in Fig. 1 is derived from residence permits, which only cover legal foreigners. Estimates on illegal ones have been proven to fail, but varies from 10 to $40 \%$ of the legal one (Strozza and Venturini, 2002).

According to the 2001 census and to more recent surveys (2008b, ISTAT) on residency permits, $63.6 \%$ of foreign residents were located in the North while only $25 \%$ in the Centre and $12 \%$ in the South and Islands. In general they had unskilled jobs, although in a few cases they had higher educational qualifications. Men usually worked in the construction industry, in agriculture and manufacturing, while women worked in family services and services in general, while a few also worked in industry (2008a, ISTAT).

Foreign migration is a quite recent phenomenon for Italy, although it has a long tradition of international emigration: first overseas to the Americas, then mainly to the Northern European countries. Italy has also experienced extensive internal migration from the less developed areas of the South, but also of the East, to the richer areas of the North-West. Emigration from the South to the Northern regions once represented 33\% of Southern employment. With the Second World War, international migration ceased, although it continued in Europe and in Italy, but at a lower rate. Migrations between Northern and Southern Italy have declined steadily since the 1970s despite the substantial increase in the unemployment differential.

Drawing on social security data, Figure 2 presents the last thirty years of internal migration by natives ${ }^{4}$ : the North-West is by far the main destination area. Emigration has taken place mainly from the Southern regions to all possible destinations, but most notably to the North-West and Centre. The North East inflows went mainly the North West while a negligible amount of people moved from the North-West to the South. Finally, inflows from the Centre have been insignificant throughout the period.

After a period of decline, in the second half of the 1990s inflows acquired new strength, especially in the North-East.

Faini et al. (1997), using a special edition of the quarterly Labour Force Survey, show that the fall in mobility levels in Southern Italy may have been driven by a combination of demographic factors, high mobility costs, and inefficiencies in the

\footnotetext{
${ }^{4}$ Information on internal migration can also be derived from the ISTAT Local registers which report the change of residency. However, these are flows data only.
} 
job matching process sufficiently strong to offset the influence of rising unemployment differentials. Also Attanasio and Padoa Schioppa (1991) point out the role of mismatches in the labour market in explaining the low mobility and the high unemployment in the South. More specifically, Cannari et al. (2000) show that the North-South housing price differential is a notable factor in explaining the downward trend of geographical mobility.

Since 1995, however, interregional mobility has been increasing. Using information on change of residency reported at local registers, Piras (2005) shows that the propensity to emigrate increases with the level of education, and that there is evidence of a brain drain from the Italian Southern regions. ${ }^{5}$

Figure 2 shows on the one hand a general increase of foreign immigration in all the destination areas, but on the other, a decline in migration from the South, with the exception of the North-East, where, however, the number is exceeded by foreign migrants, suggesting competition between the two groups of workers (Brucker et al. 2009).

\section{2-Assimilation literature: some recalls.}

The economic literature on the assimilation of immigrants starts with the pioneering work of Chiswick (1978) and the seminal contributions by Borjas (1985) and La Londe and Topel (1992), all of which were based on the USA Census.

The overassimilation initially found (Chiswick 1978, using a single census) was attributed to positive self-selection by migrant workers: that is, they were more entrepreneurial, more talented and less risk averse. The under-assimilation of immigrants found by Borjas (1985) in the USA was attributed to the lower quality of the most recent cohorts.

The differing quality of cohorts at the time of immigration is due to various factors: changes in immigration policy, so that individuals with different characteristics are selected; different economic conditions in the destination country which alter the nationality mix of immigrants and thus gives rise to changes in their productivity; and changes in the composition of the cohorts due to non-casual repatriation. The same result of under-assimilation was reported by La Londe and Topel (1992), but it was attributed to the worse economic conditions in the destination country at the time of arrival, which offered few career prospects to the migrants.

This debate is conditioned by the rich set of information available from the USA Census, which, however, raises a series of methodological problems more easily solved by longitudinal data. The study on true longitudinal data conducted by Lubotsky (2007), however, reaches a similar conclusion: immigrant wages increase by about $10-15 \%$ in the first 20 years in the US but not enough to offset the $35-40 \%$ immigrant/native wage differential. Assimilation is a function of the immigrants' human capital: while college degree immigrants earn $30 \%$ more than the average natives, immigrants who arrive with low schooling levels never attain the earnings of the average natives (Card 2005). ${ }^{6}$

\footnotetext{
5 This last source reports the number of both workers and family members who change their residency, but no labour information. Hence it is not suited for any assimilation study. We overcome this problem by using the WHIP - Work Histories Italian Panel - which enables us to discriminate among workers on the basis of their place of birth.

${ }^{6}$ David Card (2005) stresses that it is probably more relevant and interesting to understand if the second generation of migrant is assimilating, and that it would be a more complete measure of the long run parental assimilation process. His results show that if immigrants working in the USA labour market earn today less than natives (but not a lot less), and the different education levels explain 10\%
} 
Economic assimilation research in Europe started a little later and has been mainly based on national panel data. The core of empirical models has been the immigrant's education before arrival, and after arrival, his/her acquisition of human capital on the job before and after immigration, and his/her proficiency in the language of the destination country, which also favors the second generation's integration. Chiswick (1991) found that the knowledge of the natives' language was crucial for assimilation into the British labour market, a result confirmed by Shields and Wheastley Price (2002), and also by a more recent study by Dustmann and Van Soest (2002) and Dustmann and Fabbri (2003).

In Denmark ${ }^{7}$ Neilson et al. (2000) found that a foreigner's job assimilation increases, not with the number of years that $\mathrm{s} /$ he has been in the country, but with the number of years that $\mathrm{s} /$ he has worked in the country. These authors thus emphasize that workers increase their human capital only when they are working, not just during their presence in the destination country. Kee (1994), in the Dutch case, concludes that one of the causes of the lack of assimilation of foreign workers is that only few immigrants continue their studies in the receiving country. Also Grainer and Marciano (1975) in the French case and using data from the 1968 census in a descriptive way, reach the same conclusions, suggesting that the lower average wage for foreigners with a nuclear family is mainly due to less investment in human capital, and this varies substantially across ethnic groups.

The process of assimilation, however, also depends on the characteristics of immigrants who remain in the destination country. As Borjas (1985), Borjas and Bratsberg (1996) and Dustmann (2003 and 2007) stress in their articles on the return decisions of migrants, foreigners who remain may be either the best or the worst of the group. ${ }^{8}$ The migrant decides to return if the migration project fails or, in the opposite case, if the migration project is very successful and allows the migrant to return home and start a business there. If those who remain are the best, the empirical estimates of assimilation will be biased upwards (over-assimilation), while if those who remain are the worst, the estimates will be biased downwards (underassimilation); in both cases they are inconsistent. The modeling of the re-migration decision - as Dustmann $(1996,2003)$ terms it - is used as a first step to control for the selectivity of the assimilation pattern. Dustmann (2003), Costance and Massey (2003) and Fertig and Schurer (2007) modeled the return decision as a migration decision function of the income differential; and Dustmann (2003) developed the role played by income in the destination countries, using family ties as instruments. Following recent research on return migration and return migration policies; e.g. Cassarino (2007) for the Maghreb areas and Mansoor and Quillin (2006) for many European and Central Asian countries, Venturini and Villosio (2008) instead focus on the role played by economic prospects in the countries of origin in attracting migrants back home.

of the gap, the second generation increases its education level, with a generational transmission of education (effect of the education of the father on the education of the son or daughter) equal to the one of the other family.

${ }^{7}$ They used administrative data and test a random effect model on foreign wages.

${ }^{8}$ Since his 1985 article Borjas has stressed the selectivity of the migration decision as a function of the human capital return of migration. In his 1996 article with Bratsberg he also considers the selectivity of the return decision using a cross-sectional approach and always referring to a Roy return of human capital model. 
Other relevant variables are related to the labour market variables which determine the worker's future prospect. Not only is the business cycle upon arrival crucial for the immigrant's assimilation but so too is the sector of employment, which is affected in different ways by technological innovation. Rosholm et al. (2006) found that, both in Sweden and Denmark, between 1985 and 1995, job opportunities for male immigrants deteriorated. However, by using a panel of administrative data they showed that the worsening situation was independent of the different market trends in the two countries. It was due instead to structural changes in the markets, where the labor demand was for workers with high communication skills, with the consequence that immigrants were at a disadvantage.

An additional component of the assimilation pattern is imputed to the migrant community (Borjas, 1992, 1995, Cutler and Glaeser, 1997) and has been revised by Hatton and Leigh (2007), who abandon the individual analysis of the assimilation and shift to analysis of assimilation by the community. The community can exert a positive effect by favouring the job search process, but it can also have a negative one by reducing the social integration-interaction of immigrants, namely knowledge of the host country's language (see e.g. Chiswich 1991, Dustmann and van Soest 2002, Shields and Wheatley Price, 2002), and in general of the informal rules on living which prevail in the destination countries. Policies have been adopted to discourage the agglomeration of immigrants in particular areas, which has been considered a cause of low linguistic proficiency and as reducing the incentive to move in search of better job opportunities. In the North-European countries the distribution of refugee immigrants around the country seems to be less efficient in integrating foreigners than the previous agglomeration (Husted et al. 2001).

\section{The assimilation model in the presence of return migration}

The assimilation model used here is the traditional human capital model adopted by Chiswick, in 1978. We explicitly include measures of human capital acquired on the job and out of the job and controls for selection in return migration.

The dependent variable is a measure of the individual wage $\left[\mathbf{y}_{\mathbf{i t}}\right]$ which depends on individual fixed effects $\left[\boldsymbol{\alpha}_{\mathbf{i}}\right]$, individual time variant human capital variables $\left[\mathbf{x}_{\mathbf{i t}}\right]$, worker's job characteristics $\left[\mathbf{z}_{\mathbf{i t}}\right]$ and time invariant individual characteristics $\left[\mathbf{h}_{\mathbf{i}}\right]$. In addition we control for different economic cycle $\left[\mathbf{m}_{\text {rst }}\right.$ ] which affect both the region $[\mathbf{r}]$ and the sector [s] where the workers are employed and the size of the migrant's community $[\mathbf{c}]$ in the destination area $\left[\mathbf{k}_{\mathbf{c r t}}\right]$ which can favor or reduce the economic integration of the migrants.

The process of assimilation, however, also depends on the characteristics of immigrants who remain in the destination country. If there is a systematic link between the decision to stay and labour market outcomes, a fixed effect estimate eliminates the bias. If it is not systematic, even fixed effect estimates give unreliable parameter estimates and we need to proceed in two stages.

The true but unobservable utility of leaving the destination country, $\mathrm{S}^{*}$ it , is:

$\mathrm{S}^{*}{ }_{\mathrm{it}}=\beta \mathrm{X}_{\mathrm{it}}+\delta \mathrm{R}_{\mathrm{t}}+\mathrm{v}_{\mathrm{i}}$ 
if $\mathrm{S}^{*}{ }_{i \mathrm{t}}>0$ then the migrant leaves

if $\mathrm{S}^{*}$ it $\leq 0$ then the migrant stays

where $\left(\mathrm{X}_{\mathrm{it}}\right)$ are individual explanatory variables which are common to the assimilation equation and the return decision, $\left(\mathrm{R}_{\mathrm{t}}\right)$ are additional variables which affect only the re-migration decision and which serve as identification restrictions; $v_{i}$ is an individual error component.

We observe only the leaving of the migrant $S=1$ or his staying $S=0$.

Two solutions have been implemented to estimate the probability of leaving the destination country: in the first case the probability of leaving the destination country $(\mathrm{S}=1)$ is modeled within a probit random effect model which controls for the years of presence in the destination country; in the second case, a proportional hazard function is adopted in modelling the return decision which endogenizes the path dependency in the probability of staying.

In the first case assuming that the individual component $v_{i}$ is randomly distributed among the individuals with a normal distribution $\mathrm{N}\left(0, \sigma_{v}{ }^{2}\right)$, the probability of leaving the destination country $(\mathrm{S}=1)$ is (II).

$\operatorname{Pr}\left(\mathrm{S}_{\mathrm{it}}=1\right)=\Phi\left(\beta^{*} \mathrm{X}_{\mathrm{it}}+\delta^{*} \mathrm{R}_{\mathrm{t}}\right)$

where $\beta^{*}=\frac{\beta}{\sigma_{v}}$ and $\delta^{*}=\frac{\delta}{\sigma_{v}}$

The $\left(\mathrm{X}_{\mathrm{it}}\right)$ are variables at individual level such as firm size and sector in which the worker is employed and the worker's country of origin; $\mathrm{R}_{\mathrm{t}}\left(=\mathrm{Z}_{\mathrm{ct}}+\mathrm{W}_{\mathrm{it}}\right)$ is composed of the macro-economic variables of the countries of origin as attractors of migrants back home $\left(\mathrm{Z}_{\mathrm{ct}}\right)$ : GDP and its growth ${ }^{9}$, and the individual variables $\left(\mathrm{W}_{\mathrm{it}}\right)$, which comprise age at entry and years of presence in the destination country and its square, and also the share of months spent in irregular employment relative to regular employment (see section on results). Our specification aims at capturing the two different forces driving movements abroad: one voluntary and the other involuntary. Foreign workers, in fact, may be driven by different motivations (dissatisfaction with career prospects in the destination country, or lack of opportunities).

In the second case the return decision is modelled with a proportional hazard function $\mathbf{h}(\mathbf{t i})$ of the probability of leaving the host country at time $t$ conditional on surviving to time $\mathrm{t}-1$. The proportional hazard rate model assumes that the covariates have a multiplicative effect on the hazard function, given the values of the covariates and the respective survival time $(\mathrm{t})$.

\footnotetext{
${ }^{9}$ The attempt to introduce also the income dispersion in the origin country to capture the different income opportunity has been abandoned by the difficulty of good time series income dispersion. http://www.wider.unu.edu/research/Database/en_GB/wiid/ presents a large amount of information on income dispersion but their time series dimension is not always reliable, and different values are frequently induced by changes in the methodology adopted, not by a real change in the income distribution. The other dataset of Freeman and Osterndoorp http://www.nber.org/oww/, which has recently been used by Belot and Hatton (2008) and Grogger and Hanson (2008) does not use the panel structure of the dataset and calculates an average wage premium for each country using all the annual information available.
} 


$$
h\left(t_{i}\right)=h_{0}(t) g\left(\mathrm{X}_{i t}, R\right)
$$

where $h_{0}(t)$ is the baseline hazard function, the hazard for the individual when all independent variable values are equal to zero, and $g\left(X_{i t}, R\right)$ is a function of the covariates. ${ }^{10}$

We include the same covariates as in (II) i.e. individual variables $\left(\mathrm{X}_{\mathrm{it}}\right.$ that affect both the assimilation process and the re-emigration decision (with the exception of year of presence) and additional variables $R$ (both macroeconomic variables $Z_{c}$ and individual ones $\mathrm{W}_{\mathrm{i}}$ ) that affect only the decision to re-emigrate.

The assimilation equation is augmented by a selection term for the return migration:

$$
y_{i t}=\alpha_{i}+x_{i t} \beta+z_{i t} \delta+h_{i} \gamma+k_{c r t} \xi+m_{r s t} \eta+\lambda_{i t} \omega+\tau_{t}+\varphi_{r}+\phi_{s}+\varepsilon_{i t}
$$

Where $\left[\lambda_{\text {it }}\right]$ is the Inverted Mill Ratio that capture the Heckman error correction when the selection model (I) is used; or the log of the hazard rate when the selection model (II) is chosen; $\left[\boldsymbol{\tau}_{\boldsymbol{t}}\right]$ are time fixed effects, $\left[\varphi_{\mathrm{r}}\right]$ are region fixed effects, $\left[\phi_{\mathrm{s}}\right]$ are sector fixed effects and $\left[\boldsymbol{\varepsilon}_{\mathrm{it}}\right]$ an idiosyncratic error component.

\section{4-Description of the data and the variables used}

The only longitudinal dataset which enables distinctions to be made among different types of immigrants, foreigners and natives, is the WHIP - Work Histories Italian Panel ${ }^{11}$ a database of individual work histories based on Italian social security archives (INPS).

The reference population is made up of all the people - Italian and foreign - who have worked in Italy even only for part of their working careers as employees or selfemployed workers or have received income support or pensions from the INPS.

Open-ended contracts in the public sector and selected professions which have autonomous social security funds (i.e. lawyers or notaries) are excluded (about 15\% of the labour force). This limitation is not particularly important for foreigners, who are rarely employed in the public sector, where entrance is made more difficult by the presence of national public competitive examinations, while it is more important for the analysis of the integration of native immigrants, especially women, who frequently participate successfully in national competitive examinations and are assigned to jobs in other areas.

Only the WHIP section concerning dependent employment is used in this paper. This is a linked employer-employee database that combines individual and job characteristics from 1985 to 2003 . It is a panel with no attrition because it is compulsory for firms to provide information about their workers to INPS.

We thus restrict our analysis to dependent employment in the private sector. Besides public-sector employees and self-employed workers, also workers in the agricultural sector (5\%) and domestic workers $(4.8 \%)$ are excluded.

\footnotetext{
${ }^{10}$ Generally, $g\left(x_{j}\right)$ is assumed to be equal to the relative risk $\mathrm{e}^{\mathrm{x} j \mathrm{\beta}}$. The model is estimated assuming $\mathrm{h}_{0}(\mathrm{t})$ to be a Weibull distribution, thus $h_{0}(t)=\mathrm{pt}^{\mathrm{p}-1}$, where $\mathrm{p}$ is the shape parameter to be estimated from the data. Very similar results are also obtained without imposing $\mathrm{h}_{0}(\mathrm{t})$ to be a specific distribution, following the Cox partial likelihood estimation.

${ }^{11}$ Developed at the LABORatorio R. Revelli (more information can be found at www.laboratoriorevelli.it/whip).
} 
This last limitation is important for analyses of foreign labour market integration because a large share of immigrants work in these two sectors (according to the ISTAT Labour Force Survey 2008, agriculture represents $3.9 \%$ of foreign employment, and domestic workers 18.7\%). In particular, given the female monopoly in domestic services and its growing importance, the share of females in the number of total residency or work permits is much larger (about 40-45\%) than that reported in the WHIP dataset, where male employment dominates (84\%). However, agriculture and domestic work have very high shares of illegal employment, and their exclusion from our analysis increases the homogeneity among the sectors. We would also point out that studies on family migration describe female migrants as followers in the migratory process and as secondary workers. Hence we expect larger differences among the three groups in this case. This feature is not limited to foreign immigrants alone; it is also distinctive of the native immigrants that were attracted to the North by the booming manufacturing industry, and whose families followed later.

For all these reasons we exclude women from the analysis. Moreover, in order to avoid measurement errors due to the limited number of observations for foreigners in the first years, we restrict our focus to the period 1990-2003, when most of the foreign inflows started (see Figure 1) and to (male) workers aged 18-45 in order to compare foreigners with the most homogeneous group of Italian workers.

With this dataset we can distinguish among different types of workers: Foreign immigrants, Native immigrants and Locals.

1. Locals : workers who are mainly employed in the geographical area of birth;

2. Native immigrants: workers who are employed in a geographical area different from that of birth;

3. Foreign immigrants: Workers born abroad.

To identify native migrants we used four large areas of origin and destination (NorthWest, North-East, Centre and South) to avoid as far as possible counting commuting workers as native migrants. Commuters are quite numerous, and according to the local register they do not change residency. Instead, by choosing changes in large areas for the identification of native migrants, we remained in line with the Italian perception of native migrants as only long-distance migrants.

Foreign workers were selected by using the place of birth (the dataset did not contain information on nationality). Only workers born outside Europe and the main industrialised countries were chosen, in order to avoid counting Italians born abroad as immigrants. Moreover, also workers born in Argentina, Brazil and Venezuela ${ }^{12}$ were excluded, because those are countries of high Italian emigration and with large return migration flows from Latin America.

The variables in the dataset made it possible to control for the age of the worker, gender, type of contract (open-ended, fixed-term, part-time), the skill level (bluecollar, white-collar, high skilled white-collar, manager), firm size, sector of economic activity, and territorial area. However, the dataset had some important limitations.

The main weakness of the dataset was the lack of an education variable. Although for native locals and immigrants we could expect that age and skill level would

\footnotetext{
${ }^{12}$ Procedure adopted for the first time in Gavosto et al. 1999 and also by Natale et al. (1999).
} 
proxy the education level, for foreigners these two variables were unfortunately not enough. We had to bear in mind, however, that the number of years spent at school would not be a good proxy for the educational level and productivity of a foreign worker because the quality of the education is very different to compare, and in addition the education usable depends upon ability in the language used in the host country $^{13}$ (for instance, Dustmann and Van Soest, 2002). This also explains why years of education in the destination country performs much better in explaining the foreign wage upgrading.

In addition we had no information about the time of arrival of foreign immigrants. However, this problem could be overcome because foreigners did not enter Italy before 1985 (when our dataset started). In addition, they entered formal and legal employment by means of repeated amnesties and were thus likely to have done so on average two years before the first legal enrolment in the WHIP dataset.

Focusing on prime age males, which is the group on which the assimilation analysis was performed, we find that on average the wage of native immigrants is $6-10 \%$ higher that the wage of local natives in all periods, but this difference is never statistically significant (see Figure 3). The wage differential between foreigners and either local or native immigrants is more irregular: it was quite stable during the 1990s but has increased since 2000. In 2003 foreign wages were on average about $75 \%$ of those of locals and about $70 \%$ of those of native immigrants; and on average throughout the 1990-2003 period, foreign workers earned 21\% less than natives and worked 20\% less than natives (Venturini and Villosio, 2008).

The differences between foreigners and natives, either locals or immigrants, are in large part due to the different characteristics of the two groups and the strong inflows of foreign migrants that Italy has experienced in the last years (Table 1).

Foreign migrants are younger than local workers, who are also younger than native immigrants. In fact migration from the South to the North took place mainly after the Second World War and continued at a slower pace, while foreign migration is much more recent. Thus foreign workers make up the youngest group.

Native immigrants are relatively more present in the large and very large firms which dominated Italian development during the 1960s, while foreign migrants are concentrated in small firms, which instead dominated economic development during the $1980 \mathrm{~s}$ and 1990s. Moreover, $25 \%$ of foreign migrants are concentrated in very small firms (1-20 employees) against $7 \%$ and $11 \%$ for native immigrants and for locals.

While native locals are employed throughout the country, native immigrants are mainly employed in the North-West. During the 1960s, this area was the booming Fordist industrial area which attracted labour from all over the country. Foreigners instead are mainly located not only in the North-West but also in the North-East; the area which on the contrary boomed during the 1980s and 1990s.

Blue-collar employment dominates in all the groups, but for foreigners blue-collar work represents $93 \%$ of total employment. Blue-collar employment is also important among native immigrants because they moved to the North when labour demand was concentrated in large manufacturing companies. Finally, foreign immigrants are highly concentrated in the construction sector.

\footnotetext{
${ }^{13}$ For instance, many Filipino maids cannot use their English language skills because nobody speaks English in the household where they work.
} 
Foreigners from Africa dominate the other ethnic groups, followed by workers from Eastern European countries, who form the group that has grown most rapidly in recent years.

To capture the effect of human and social capital on the wage assimilation two variables were constructed $\left[\mathrm{x}_{\mathrm{it}}\right]$.

The first referred to human capital accumulated on the job - experience in the current and previous jobs - and it was measured by the number of months in regular employment.

The second variable measured the months spent out of the "job" which might represents periods devoted to education, employment in sectors not covered by the dataset, unemployment, irregular employment and, for foreigners, also return back home for a while.

This second variable could thus play either a positive role in the labour market, by capturing the acquisition of human capital in the underground economy or the acquisition of more general social capital out of the labour market, or a negative role by reducing human capital accumulation. And the role could differ according to the group of reference. For locals, the periods of non-employment were expected to affect wages negatively, while for native immigrants both options were possible: they could acquire human capital working illegally or in another sector or they could be unemployed and thus have a negative impact on wage. In the case of foreign immigrants the negative impact should be lower because a longer presence in the host country, even if not in employment, could positively affect at least the migrant's social capital which has a positive return in the labour market. ${ }^{14}$

Given the recent inflows of foreigners, these have a lower presence than natives in the Italian labour market both in employment and not in employment, while native migrants seem to be less stable in employment than locals (less in employment and more in non-employment).

To control for the demand side and in particular the different trends in the sectors of economic activity, we included in our specification also two macroeconomic variables: the change in the value added by sector and region and the unemployment rate by region. This was done because we wanted to control for the different trends of the sectors where workers were employed and which affected their wages.

Finally, the role of the community of the migrant in the destination area $\left[\mathrm{k}_{\mathrm{crt}}\right]$ was captured by the share of the migrant worker community (nationality for foreigners and region of birth for native migrants) in regional total employment. Anderson et al. (2009) show that the quantity and quality of the enclaves matter in the foreigners wage upgrade. Hatton and Leigh (2007) stress the long-term effect of the community variable, and even use 10-year lags. Unfortunately, the migration phenomenon in Italy is quite recent, and we had too few observations to use long lags such the one suggested by Hatton and Leigh.

${ }^{14}$ The sum of the two variables is the best proxy available for the presence of foreign migrants in the country. 


\section{Results}

\subsection{Return migration}

According to our model (IV), the first step in the empirical analysis was estimation for foreigners of the probability of leaving; modelled both with a probit model (eq. II) and with a hazard function (eq. III).

The issue of return migration has received increasing attention in the literature, and in order to draw conclusions on the performance of immigrants in the labour market it is important to know whether there is selection in migration returning flows. Contrary to others, the WHIP dataset unfortunately does not provide information on exactly where workers go when they leave legal employment. ${ }^{15}$ When they leave the dataset, they may move to long-term unemployment, to the underground economy, to sectors not covered by the dataset (public sector or self employment), or to other countries.

The selection process is more likely for foreigners than for natives: the hazard ratio of exiting definitively for foreigners is 0.5 higher than the hazard of locals and native immigrants, even when individual, job and career characteristics are controlled for. ${ }^{16}$ Although we do not exactly know the destination of the selection process, it is likely that the majority of foreigners have moved abroad. The literature shows that temporary migrations are frequent, and often the rule rather than the exception (see Dustmann 1996, and Venturini 2007 for an overview). Even if in the short run they may transit into unemployment or irregular jobs, if they are unable to find a legal job again, in the medium run they will leave the country.

Whatever the reason, the stronger effect of selection among foreigners than among natives points up the need to control for selection bias in the wage equation. The empirical results will show whether and how migrants are self-selected, i.e. if they are the best or the worst in terms of unobservable skills and abilities.

This problem did not arise for native migrants, who were no different from locals in the probability of leaving the dataset, and who, given the dataset available, were followed in their movements across the country.

In order to capture all possible destinations (movements abroad, entry into long-term unemployment or irregular employment), variables for the country of origin as well as variables related to the job and career characteristics were included in the specification of equations II and III (see section 3).

The results from model II (see Table 2) show a strong negative duration dependence (the probability of leaving increases the longer the migrant is in the country) and demonstrate that the choice of a hazard model for the selection equation is particularly appropriate.

The hazard model was estimated by assuming $\mathrm{h}_{0}(\mathrm{t})$ to be a Weibull distribution thus $\mathrm{h}_{0}(\mathrm{t})=\mathrm{pt}^{\mathrm{p}-1}$. The value of the shape parameter [p] estimated from the data was 1.85 ,

\footnotetext{
${ }^{15}$ The most recent research that highlights the importance of return migration (Dustmann 2003, Fertig and Shurer 2007, Costant and Massey 2003) uses the GSOEP, which reports among the reasons for non-response the category "moved abroad", and uses this information to identify a return migration.

${ }^{16}$ Results from a duration model on the probability of leaving the WHIP dataset, estimated on the three groups of workers pooled (foreigners, native immigrants and locals). Covariates were: age, wage, occupation, tenure, firm size, sector, year of entry and dummies for foreigners and native immigrants. The full set of results is available from the authors upon request.
} 
meaning that the hazard of failure increases with time at a decreasing rate $(0.5<1 / \mathrm{p}<1)$. This result confirms the negative duration dependence, and therefore the temporary character of the migration project.

The other results shown by both models (Table 2) are that the economic growth of the origin country attracts emigrants back; and that the younger the age at which the migrant enters employment, the more likely it becomes that he will remain. The last variable included in this specification (Share of irregular employment) was a proxy for the difficulty of the worker in holding a stable job. It was computed as the number of months spent out of employment (before leaving for good) and the number of months in employment. The results show that the less formal the job, i.e. the more the migrant is working in the informal economy or is unemployed, the less likely it becomes that the migrant will remain.

\subsection{Assimilation results}

The second step in the analysis was estimation of the assimilation equation augmented, for foreigners, by the selection term for return migration.

The equation was estimated by an OLS fixed effects estimate ${ }^{17}$ to control for unobserved heterogeneity among individuals (results reported in Table 3).

As expected no striking differences were found among the three groups of workers. The Italian labour market is, in fact, quite closely regulated and collective agreements cover both unionised and non-unionised workers. However, since the 1993 Income Policy Agreement, wage variability has increased because firms are allowed to adjust their wage structure according to their economic performance and to local labour market conditions (Devincenti et al. 2008).

Starting from the selectivity control, the Inverse Mills Ratio coefficient (significant at $10 \%$ level) as well as the log hazard rate ${ }^{18}$ (significant at $1 \%$ level) indicate a positive correlation between the error terms in the return decision and the wage function. Thus, the higher the expected weekly wage, the higher is the probability of leaving. The unobservables that positively influence the wage of migrants negatively influence their decision to stay. Other things being equal, foreign workers who earn more are more likely to leave their present employment, while the less remunerated are less likely to abandon the present job. This results thus shows that the main factor driving permanent movements out of employment is the lack of opportunities, and that their most likely destination is a foreign country (if the best leave they are unlikely to be unemployed or in an irregular job), and also it limits the weaknesses of our data explained in section 5.1.

Similar selection is not unusual: it was found by Constant and Massey (2003) in their analysis of guest-workers in Germany in 1984; it was found also in some cohorts of Fertig and Shurer's (2007) analysis of the assimilation of migrants who arrived in Germany between 1969 and 1973, and among Finnish return migrants from Sweden (Rooth and Saarela 2007).

\footnotetext{
${ }^{17}$ Note that, given our sample selection as explained in section 1 and the type of estimation described in section 2, the time invariant individual characteristics $h_{\text {irs }}$ in the equation are eliminated.

${ }^{18}$ Since the average hazard rate is $>1$ (see table 2 ) the log hazard rate is on average positive
} 
All the human capital variables are significant with the expected sign. The age variable is more important for the locals, even if it declines at a higher rate, followed by native immigrants and foreigners, while experience on the job is more important for native immigrants than for the other two groups of workers and declines at a very low rate for the foreign migrants.

Periods spent out of employment have a negative effect on the local workers' wage (as in Edin and Gustavsson 2008), while they are not significant for native immigrants and for foreign ones. Immigrants are a more mobile section of the labour force, so that foreigners may increase their social capital while they are out of employment and thus not decrease in productivity. Nor are native immigrants negatively affected by the time off the job. This result highlights, as in the cases mentioned before, the importance of experience on the job for the assimilation of immigrants, but also the lesser damage caused by time off the job for the immigrants.

The macro variables contribute to explaining the wage dynamics of the three groups of workers in different ways. The increase in value added in the sectors and regions pushes up the wages of all groups, but foreign migrants are more sensitive to it. The regional unemployment rate matters only for the Italians: it slows down the wage growth of native locals or native immigrants. This result is as expected because unemployment is mostly made up of native unemployed workers with skills different from those of foreign migrants: the inverse relationship between unemployment and wages holds only for native workers.

Last, but not least, the community variable is not significant in the case of foreign immigrants, while it is significant for native immigrants, and with a negative sign. This is not an unusual result: for instance, Hatton and Leigh (2007) found a negative sign for the community variable in the UK. If we recall that the variable adopted is not a proxy for the size of the immigrants' community but represents the size of the community of workers coming from the same area, the negative sign is less puzzling. The results point up a supply effect which reduces the wage growth among native immigrants. Probably, the size of the foreign migrant community is too small for it to play a similar role.

We now turn to the human capital variable and to the wage assimilation pattern of immigrants. Inspection of the accumulated effect of human capital variables (Age and Experience) shows that foreign male immigrants never assimilate with native immigrants and the locals, because both the coefficients on age and experience are smaller than the respective ones. However, periods spent out of employment have a negative effect on wage profiles only for locals, while they do not affect the immigrants' human capital.

Figure 4 shows graphically the accumulated effect of human capital variables on wages for the three groups of workers. The profiles of locals and native immigrants are not statistically different from each another, while they are statistically different from that of foreigners. A test for common coefficient restrictions was run on a pooled regression of (a) native immigrants and locals, (b) foreigners and locals. The null hypothesis that all the coefficients for native immigrants and foreigners are zero was respectively accepted for native immigrants $[\mathrm{F}(1,356376)=0.58$, Prob $>\mathrm{F}=$ $0.4481]$ and rejected for foreigners $[F(1,323473)=6.00$, Prob $>F=0.0143]$. 
Workers from the different groups start their career at the same wage level. However, as experience increases, the profiles of foreigners and natives start to diverge, showing a wage gap of about $10 \%$ after 5 years of experience in the labour market and more than $15 \%$ after 10 years of experience.

However, the graph does not include the effect of periods spent out of employment, which have a negative effect on natives' wages and do not penalize foreigners' ones. To our knowledge, our approach is the first that addresses the assimilation of native immigrants and, although this result has been discussed in the sociological literature, it has not been verified with a large dataset.

The increasing difference between the locals' and foreigners' wage profiles supports the interpretation of the under-assimilation of foreigners, who do not close the wage distance with native immigrants, even if they are likely to improve their language skills and increase their social capital in the destination area. Language and social capital, however, matter a great deal because the native immigrant's wage profile is close to that of the locals.

\subsection{Sensitivity analysis}

In order to control for heterogeneity among foreign workers better, we now focus on the assimilation pattern of different national groups. The dataset did not allow analysis by single nationalities: many groups are too small, and the analysis by main immigration areas performed in Venturini and Villosio (2008) is not very convincing because it mixes too many different ethnic groups. We thus selected the main nationalities - Moroccan, Senegalese, and Albanian - and investigated their assimilation patterns.

We also controlled for the impact of the economic cycle: we selected the native and foreign workers entering the labour market in the same years, 1991 and 1992, and followed their assimilation patterns.

Finally, the last insight into the assimilation pattern concerns income distribution: we divided the above group of workers (those entering in employment in the years 1991 and 1992) between those receiving a wage above the median on entry and those below the median.

\subsubsection{Assimilation of different ethnic groups}

The three foreign groups, Senegalese, Moroccan and Albanian, which are the largest foreign groups in Italy, differ in terms of time of arrival in Italy, sector specialization and level of education ${ }^{19}$ (see Table 4). Hence different assimilation patterns were expected.

The results show that the share of blue-collar workers is lower among Albanians than among Moroccans and Senegalese. Albanians also account for the lowest share of workers in the north-eastern part of Italy and for the highest share in very small firms. Moroccans have the lowest wages, while the Senegalese the highest. However, the high Senegalese wages are due to a composition effect: they are older and have more experience in the Italian labour market on average than the other two groups. In fact, the table also highlights the difference in the timings of entrance into the Italian

${ }^{19}$ According to ISTAT Labour Force Survey, in 2006 the share of people from Senegal with primary education or less was $88 \%$, compared to $80 \%$ of Moroccans and $68 \%$ of Albanians. 
labour market. The Albanian workers are the most recent incomers. This difference among ethnic inflows is reflected in the differences in average age and total job experience.

The three groups also have different sector specializations: mainly manufacturing for Senegalese workers, construction for Albanians.

Interesting differences emerge in the assimilation patterns. The age variable, which probably captures education, is more important for Moroccans but lower than that for natives, while experience is particularly rewarding for Moroccans, even higher than for natives, and for Albanians. The selectivity coefficient is significant for all the groups, but it is higher for Moroccans, who thus suffer more from limited wage opportunities in the Italian labour market ${ }^{20}$.

The experience-wage profiles show that workers from Albania are very similar to natives at entrance in the labour market, but their career measured in terms of wage, proceeds at a lower pace than that of locals. If this pattern is confirmed also in the future (recall that this group of immigrants has only recently entered Italy) after 10 years of labour market experience the differential between the two groups will reach $10 \%$. Although Albanian workers are the immigrants with the highest level of education, they are hired for unskilled positions, in which they seem to be stuck.

The situation is worst for workers from Senegal, who have a differential of 30\% at entrance that reaches $50 \%$ after 10 years. Moroccans are in between, with an initial differential from locals of $18 \%$ that becomes $23 \%$ after 10 years. This result shows that, even if Senegalese workers have higher wages on average, when workers and career characteristics are controlled for, they tend to be the most penalized by the Italian labour market. The community variable is significant only for the Moroccan group.

\subsubsection{Entrants in employment in 1991 and 1992, all.}

Some of the results presented in the previous section may have been affected by the different economic cycles prevailing at the time of entrance into employment and which conditioned the future wage path and the future wage assimilation process. This is a usual problem in empirical analyses of migration, but it becomes even more important in the case at hand because while native locals enter the labour market throughout the period, foreigners arrived in the late 1980s while a large share of native immigrants did so in the 1970s. Of course, age and experience capture the human capital embodied by the worker and the macro variables capture different regional and sector economic cycles, but in order to control more carefully for the differences in the assimilation pattern among the three groups, we selected a subsample comprising only workers that entered the labour market in the same period. We thus performed the estimates only with workers who had entered the labour market in the same two years: 1991 and 1992.

In this case we expected both native immigrants and locals to have the same wage pattern because they entered the labour market in a period when differences, also from a cultural point of view, among workers from different regions were less marked.

\footnotetext{
${ }^{20}$ In all the three groups the average hazard rate estimated was $>1$
} 
Table 6 sets out the results. The age variable has a higher impact on wages for locals and the experience variable for native immigrants. Hence foreign immigrants never catch up. The macro variables exert the effect already found in the general analysis: the value added is positive for all groups, and unemployment is effective only for locals. The community variable is not significant in either case.

If we compare the results on assimilation in the subsample of the entrants in 1991-92 with the overall sample results, we find a similar non-assimilating profile between foreigners and natives, and an identical profile between native immigrants and locals. However, differently from the general results, a wage differential between foreigners and natives emerges also at entrance: it is $6 \%$ at entrance, rises to $14 \%$ after five years of experience, and reaches $18 \%$ after 10 years of experience, as Figure 6 shows.

These results again point up the differences in the returns on wage by group of origin. In fact, this group of workers is mainly composed of African workers (1 out of 4 is from Senegal), who formed the first wave of immigrants, and who have the lowest wage profiles (see previous section).

\subsubsection{Blue collars by wage distribution}

The foregoing analyses indicate the existence of an ethnic differential. In this section we go into deeper detail by splitting the blue-collar workers who entered in 1991 and 1992 into two groups: those who have a wage level above the median at entrance and those below, for both locals and foreigners. ${ }^{21}$ The idea is to control for the skill level of workers. Since almost all foreign workers are manual workers we restrict the analysis to blue collars and we compare the performance of the very low skilled with those with some degree of specialization and who thus entered the labour market with an higher wage level.

The age variable is more important for workers below the median, both natives and foreigners, while experience plays a more important role in the group entering above the median wage level. Having controlled better for the skill level, the selection coefficients are no longer significant.

What emerges is a very high and increasing gap in the lowest part of the distribution between native and foreigners ( $27 \%$ at entrance, $36 \%$ after 10 years). In the higher part the differential is null at entrance, but increases with experience in the labour market and reaches $13 \%$ after 10 years. Moreover the gap within the group of natives between those below and those above the median remains almost constant in the period, while for foreigners the high differential at entrance $(43 \%$ between the foreigners with the entrance wage above the median and those below it) is decreasing (it reduces to $35 \%$ after 10 years) because the group above the median slowly loses position, ending after 10 years at a level below that of the low-skilled manual native workers. Thus, among foreign migrants, even those that seem the best lose position against natives and increase their differential. This result strengthens our conclusion concerning the probability of return being higher among the best workers.

\footnotetext{
${ }^{21}$ In this analysis we do not consider the native immigrants who behave like the locals
} 


\section{Concluding comments}

The analysis in this paper has focused on the wage assimilation of male immigrants in the Italian labour market. Italy has a quite recent history of foreign immigration but a longer history of internal migration from the Southern regions to the North. The aim of the paper has been to understand the pattern of assimilation of foreign migrants with respect to native immigrants, i.e. internal migrants, and local natives. This is a unique opportunity, like an experiment, where we have compared locals and native immigrants proficient in the language of the destination country but nevertheless immigrants.

Both groups of migrants have been compared with native locals, who represented the linguistic benchmark and the social capital of reference.

For this purpose, we used the administrative dataset on dependent employment, WHIP, which enabled us to distinguish among foreigner workers, locals, and native immigrants; a comparison not previously made. Moreover, by using this dataset we were able to build variables intended to capture human capital in the job and out of the job. A fixed effect model of weekly wage of males aged 18-45, which controlled for unobserved heterogeneity and selection in return migration, was tested. In particular, two different methods to estimate return migration were implemented.

The estimates showed the presence of selection in the return decision; those better able to earn higher wages are more likely to leave.

Foreign workers have an entrance wage similar to those of natives, but the accumulation of experience increases the wage gap with natives. Time out of employment does not negatively affect foreign wages, showing a possible general non-negative effect of the months spent out of the job, which instead prevails in the case of native locals in our sample and in other empirical studies.

Comparison between internal native immigrants and locals has shown that native immigrants are similar to locals. While only the effect of the time spent out of the job is similar for both migrant groups.

The control for the sector and regional change in value added is similar for all the groups, while only locals are sensitive to regional unemployment rate. This last result is not surprising because the regional unemployment rate is made up of local workers, while native and foreign immigrants are in more mobile segments of the labour force and are less present among the unemployed in the destination region.

In order to check the differences across different groups in terms of entrance period and origin, we analysed specific origin groups (workers from Morocco, Senegal and Albania) in a sub-sample made up of the entrants in the labour market in the same years, 1991 and 1992, and by wage level at entrance. The results show that there are differences across origin group, in that workers from Senegal are the least assimilated. The gap with natives is especially wide in the lower tail of the wage distribution.

Last but not least, the importance of the community effect is limited. It plays a negative role for native immigrants, indicating competition within the group in the labour market. Among foreigners, it is instead positive for the Moroccan group, where a supportive role is detected, while it is insignificant for the other communities, probably because they are still too small. 
The main conclusion is that comparison among the assimilation patterns of foreign and national migrants confirms that language and social capital matter for assimilation. In fact, native migrants assimilate, while foreign immigrants never close the gap with natives. If foreign migration becomes a permanent phenomenon, Italy should invest in integration policies designed to prevent the formation of a separate group of foreign workers which might provoke suspicions of discrimination against immigrants. 


\section{References}

Anderson, Frederik, Simon Burgess and Julia Lane. 2009. "Do as the Neighbours Do: The Impact of Social Networks on Immigrant Employment.” IZA Discussion Paper No. 4423, Bonn.

Ascolani, Augusto, Anna Maria Birindelli and Giuseppe Gesano. 1974. L'integrazione degli immigrati in Ambiente urbano. Risultati di una indagine a Roma e Torino. Roma: CISP.

Attanasio, Orazio and Fiorella Padoa-Schioppa. 1991. "Regional inequalities, migration and mismatch in Italy 1960-86." in Fiorella Padoa-Schioppa ed. Mismatch and labor mobility. Cambridge: Cambridge University Press.

Belot, Michel and Timothy Hatton. 2008. "Immigrant Selection in the OECD”. CEPR Discussion Paper No. 6675, London.

Borjas, George. 1985. "Self selection and the earnings of immigrants." American Economic Review, Vol. 77, pp. 531-553.

Borjas, George. 1985. "Assimilation, Changes in Cohort Quality, and Earnings of Immigrants." Journal of Labor Economics, Vol. 4, pp.463-89.

Borjas, George. 1992. "Ethnic Capital and Intergenerational Mobility." The Quarterly Journal of Economics, Vol.107, n.1, pp.123-150.

Borjas, George. 1995. "Ethnicity, Neighbourhoods, and Human-Capital Externalities." The American Economic Review, Vol.85, n.3, pp.365-390.

Borjas, George and Bernt Bratsberg. 1996. "Who Leaves? The Outmigration of the Foreign-born." Review of Economics and Statistics, pp. 165-176.

Bruker Herbert, Stefano Fachin and Alessandra Venturini. 2009. "Do Foreigners Replace Native Immigrants? Evidence from a Panel Cointegration Analysis." IZA Discussion paper n. 4438, Bonn.

Cannari, Lucio, Francesco Nucci and Paolo Sestito. 2000. "Geographic Labour Mobility and the Cost of Housing: Evidence from Italy." Applied Economics, Vol. 32, pp. 18991906.

Card, David. 2005. "Is the New Immigration Really So Bad?" Economic Journal, Vol. 115, No. 507, pp. F300-F323.

Cassarino, Jean Paul. 2007. "Return Migrants to the Maghreb: Reintegration and Development Challenges." MIREM, RSCAS/EUI, Florence.

Chiswick, Barry. 1978. "The Effect of Americanisation on the Earnings of Foreign-born Men.” Journal of Political Economy, Vol. 86, pp.897-921.

Chiswick, Barry. 1991. "Speaking, Reading, and Earnings among Low-skilled Immigrants." Journal of Labor Economics, vol.9, n.2, pp.149-170.

Constant, Amelie and Douglas S. Massey. 2003. "Self-selection, Earnings, and Outmigration: A Longitudinal Study of Immigrants to Germany." Journal of Population Economics, Vol. 16, No. 4, pp. 631-653.

Cutler, David M., and Edward L. Glaeser. 1997. “Are Ghettos Good or Bad?" Quarterly Journal of Economics, Vol. 112, pp. 827-872.

Del Boca, Daniela and Alessandra Venturini. 2005. "Italian Migration" in Klaus F. Zimmermann, ed., European Migration: What Do We Know?, Oxford University Press.

Devicienti, Francesco, Agata Maida and Lia Pacelli. 2008. "The resurrection of the Italian Wage Curve." Economics Letters, Vol. 98, pp. 335-341.

Dustmann, Christian. 1996. "Return migration - the European experience." Economic Policy Vol. 22, pp.214-250.

Dustmann, Christian. 2003. "Return Migration, Wages Differentials and the Optimal Migration Duration.” European Economic Review, Vol. 47, pp. 353-367. 
Dustmann, Christian and Yoram Weiss. 2007. "Return Migration: Theory and Empirical Evidence from the UK." British Journal of Industrial Relations, Vol. 45, No. 2, pp. 236256.

Dustmann, Christian, and Arthur van Soest. 2002. "Language and the Earnings of Immigrants." Industrial and Labour Relation Review, Vol. 55, No. 3, pp. 473-492.

Dustmann, Christian and Francesca Fabbri. 2003. "Language proficiency and labour market performance of immigrants in the UK." The Economic Journal, Vol. 113, pp.695-717.

Edin, Per-Anders, Gustavsson Magnus. 2008. "Time out of work and Skill Depreciation.” Industrial and Labour Relations Review, Vol. 61, No. 2, pp. 163-180.

Faini, Riccardo, Giampiero Galli, Pietro Gennari and Fulvio Rossi. 1997. "An empirical puzzle: falling migration and growing unemployment differentials among Italian regions." European Economic Review, Vol. 41, pp.571-579.

Fertig, Michael, Stefanie Schurer. 2007. "Labour Market Outcomes of Immigrants in Germany: The Importance of Heterogeneity and Attrition Bias." IZA Discussion Paper No. 2915, Bonn.

Fofi Goffredo. 1975. Immigrazione meridionale a Torino. Milano: Laterza, republished 2009, by Aragno Editor.

Gavosto, Andrea, Alessandra Venturini and Claudia Villosio.1999. "Do Immigrants Compete with Natives?" Labour, Vol.13, No. 3, pp. 603-622.

Granier, R. and Marciano, J.P. 1975. "The earnings of immigrant workers in France." International Labour Review Vol. 111, 143-165.

Grogger, Jeffrey and Gordon Hanson. 2008, "Income Maximization and the Selection and Sorting of International Migrants.” NBER Working Paper No. 13821, Cambridge, MA.

Hatton, Timothy J. and Andrew Leigh. 2007. "Immigrants Assimilate as Communities, not Just as Individuals.” IZA Discussion Paper No. 2538.

Husted, Leif, Helena Skyt Nielsen, Michael Rosholm and Nina Smith. 2001. "Employment and Wage Assimilation of Male First Generation Immigrants in Denmark." International Journal of Manpower, pp.39-68.

ISTAT. 2008a. Indagine sulle forze di Lavoro. Rome

ISTAT. 2008b. Popolazione straniera residente in Italia. Rome.

Kee, Peter. 1994. "Native-Immigrant Employment Differentials in the Netherlands: The Role of Assimilation and Discrimination." International Review of Applied Economics, Vol.8, No.2, pp.174-196.

LaLonde, Robert and Robert Topel. 1992. "The Assimilation of Immigrants in the U.S. Labor Market." in George Borjas and Robert Freeman eds., Immigration and the Workforce, pp.67-92, Chicago: NBER, University of Chicago Press.

Lubotsky, Darren. 2007. "Chutes or Ladders? A Longitudinal Analysis of Immigrant Earnings." Journal of Political Economy, Vol. 115, No. 5, pp. 820-867.

Mansoor, Aly, and Bryce Quillin. 2007. Migration and Remittances, Eastern Europe and the Former Soviet Union. Washington, DC: The World Bank.

Natale, Luisa, Oliviero Casacchia, and Salvatore Strozza. 1999. "Migrazioni Interne, Migrazioni Internazionali: Il Nuovo Ruolo del Mezzogiorno", in Corrado Bonifazi ed., Mezzogiorno e Migrazioni Interne. Rome: Monograph IRP-CNR No. 10, pp. 237-272.

OECD. 2009. International Migration Outlook. Paris

Piras, Romano. 2005. "Un'analisi dei flussi economici dei laureati: 1980-99." Rivista Economica del Mezzogiorno, vol XIX.

Rooth, Dan-Olof and Jan Saarela. 2007. "Selection in Migration and Return Migration: Evidence from Micro Data". Economics Letters, Vol. 94, pp. 90-95. 
Rosholm, Michael, Kirk Scott and Leif Husted. 2006. "The Times They Are A-Changing: Declining Immigrant Employment Opportunities in Scandinavia." International Migration Review, Vol. 40, pp. 318-347.

Shields, Michael A. and Stephen Wheatley Price. 2002. "The English Language Fluency and Occupational Success of Ethnic Minority Immigrant Man living in English Metropolitan Areas." Journal of Population Economics Vol. 15, pp.137-160.

Strozza, Salvatore and Alessandra Venturini. 2002. "Italy is no longer a country of emigration: Foreigners in Italy, how many, where they come from and what they do." in Ralph Rotte and Peter Stein. Eds. Migration policy and the economy: International experiences. Hanns Seidel Stiftung Studies and Comments 1 series.

Venturini, Alessandra. 2004. Post-War Migration in Southern Europe. An Economic Approach. Cambridge: Cambridge University Press.

Venturini, Alessandra. 2007. "Circular Migration as an Employment Strategy for Mediterranean Countries." CARIM Circular Migration series, No. 39.

Venturini, Alessandra and Claudia Villosio. 2006. "Labour Market Effects of Immigration into Italy: An Empirical Analysis." International Labour Review, vol.145, n.1-2, pp.91-118.

Venturini, Alessandra and Claudia Villosio. 2008. "Labour-market assimilation of foreign workers in Italy.” Oxford Review of Economic Policy, Vol. 24, No. 3, pp.517-541. 


\section{Appendix}

Table A1. Human capital, macro, community and return migration variables.

\begin{tabular}{|c|c|c|c|c|}
\hline Variables & Description & Source & & $\begin{array}{l}\text { Level of } \\
\text { aggregation }\end{array}$ \\
\hline Months of employment & $\begin{array}{l}\text { Sum of months spent in regular } \\
\text { employment up to year } t \text { since } 1985 \text { for } \\
\text { natives and since entrance in the Italian } \\
\text { labour market for foreigners }\end{array}$ & \multicolumn{2}{|l|}{ WHIP } & Individual \\
\hline Months out of employment & $\begin{array}{l}\text { Sum of months spent out of regular } \\
\text { employment up to year t since first } \\
\text { employment spell observed }\end{array}$ & \multicolumn{2}{|l|}{ WHIP } & Individual \\
\hline Log VA & Logarithm of value added in $t$ & \multicolumn{2}{|c|}{$\begin{array}{l}\text { ISTAT } \\
\text { national } \\
\text { accounts }\end{array}$} & $\begin{array}{l}\text { Branch and } \\
\text { Region }\end{array}$ \\
\hline Reg. unemployment rate & Regional unemployment rate in $\mathrm{t}$ & \multicolumn{2}{|c|}{$\begin{array}{l}\text { ISTAT Labour } \\
\text { force survey }\end{array}$} & Region \\
\hline Share of reg. foreign employment & $\begin{array}{l}\text { Share of foreign employment of the } \\
\text { individual's same country of origin on } \\
\text { total regional employment in year } t\end{array}$ & \multicolumn{2}{|l|}{ WHIP } & $\begin{array}{l}\text { Country of } \\
\text { origin and } \\
\text { Region }\end{array}$ \\
\hline Real GDP & Real Gross Domestic Product per capita & $\begin{array}{l}\text { Penn } \\
\text { Tables }\end{array}$ & & Country \\
\hline Growth rate of real GDP & $\begin{array}{l}\text { growth rate of Real GDP per capita } \\
\text { (Constant Prices: Chain series) }\end{array}$ & $\begin{array}{l}\text { Penn } \\
\text { Tables }\end{array}$ & Word & Country \\
\hline Years of stay & $\begin{array}{l}\text { Number of years of presence in Italy since } \\
\text { entrance }\end{array}$ & WHIP & & Individual \\
\hline Age at entry & $\begin{array}{l}\text { Age of foreigner when entering legal } \\
\text { employment }\end{array}$ & WHIP & & Individual \\
\hline
\end{tabular}




\section{Tables and Figures}

Figure 1. Stock of resident permits for foreigners by main areas of origin.

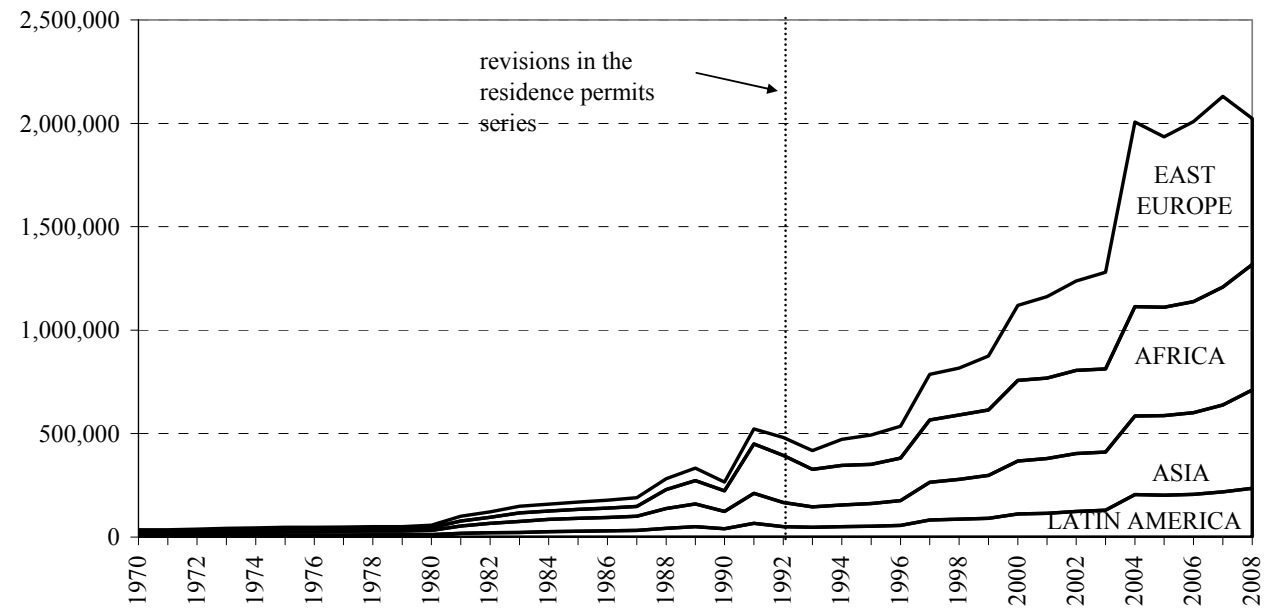

Source: ISTAT

Figure 2. Share of native immigrants and foreigners in total area employment by origin areas.

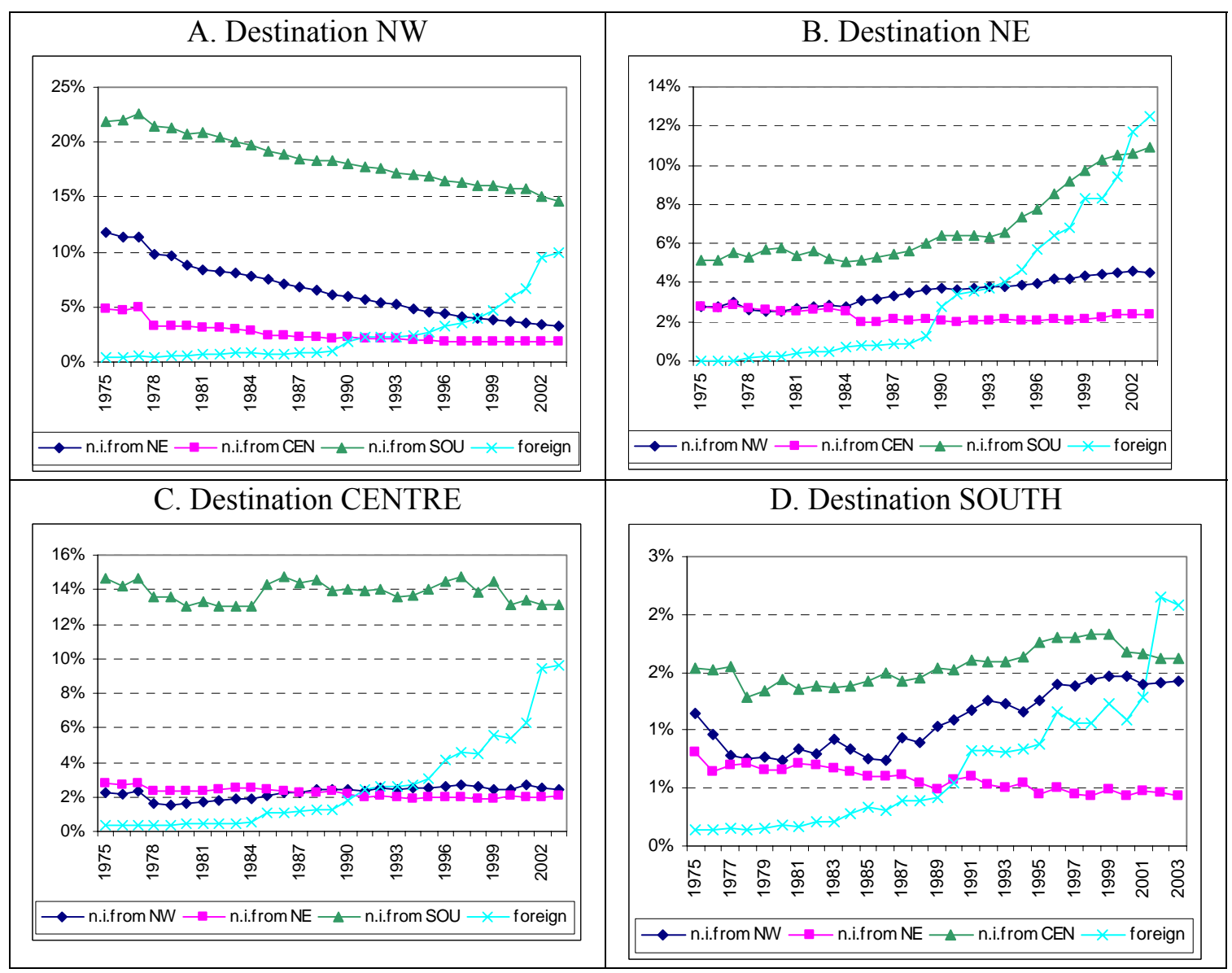

Source: WHIP and INPS data, own calculations 
Figure 3. Average nominal weekly wage by groups - Male 18-45.

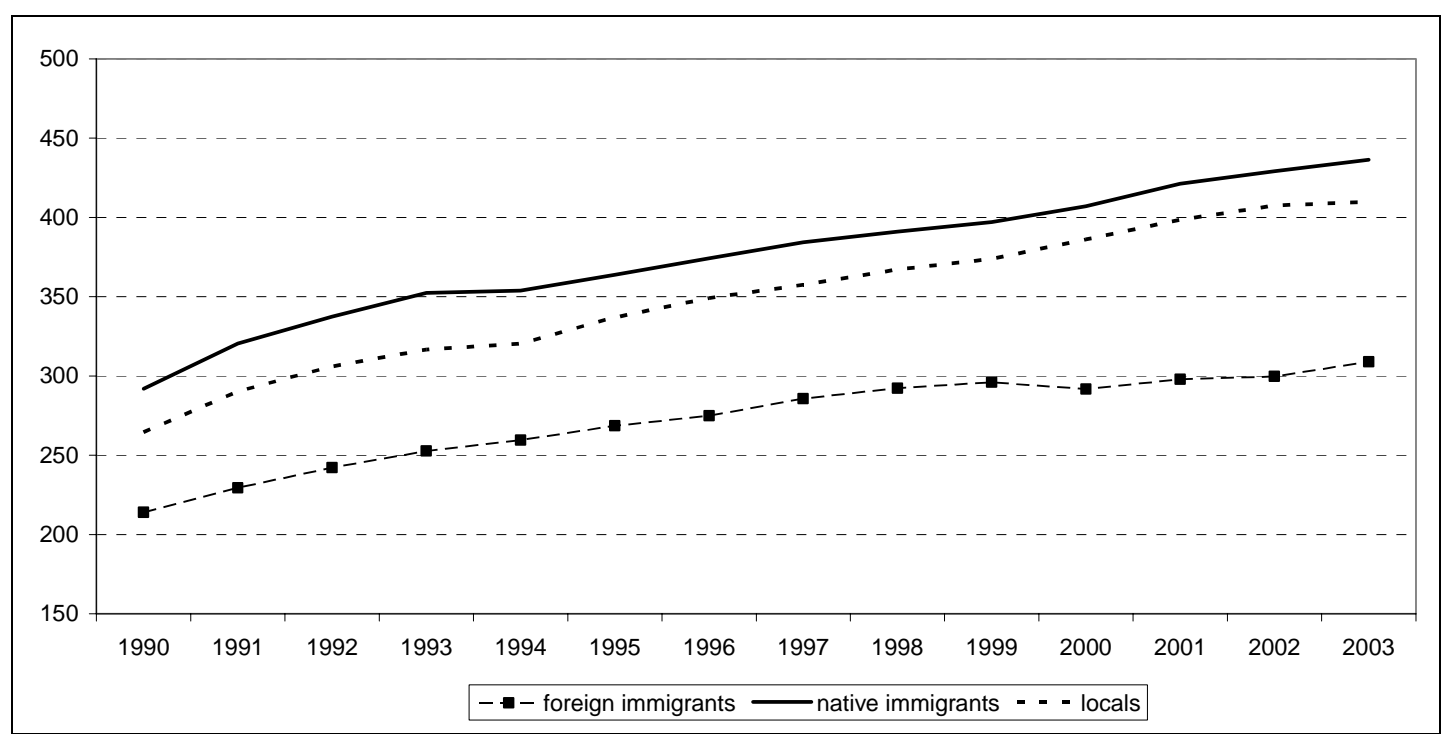

Source: WHIP, own calculations.

Figure 4. Experience- log wage profiles for foreigners, native immigrants and locals, males aged 18-45.

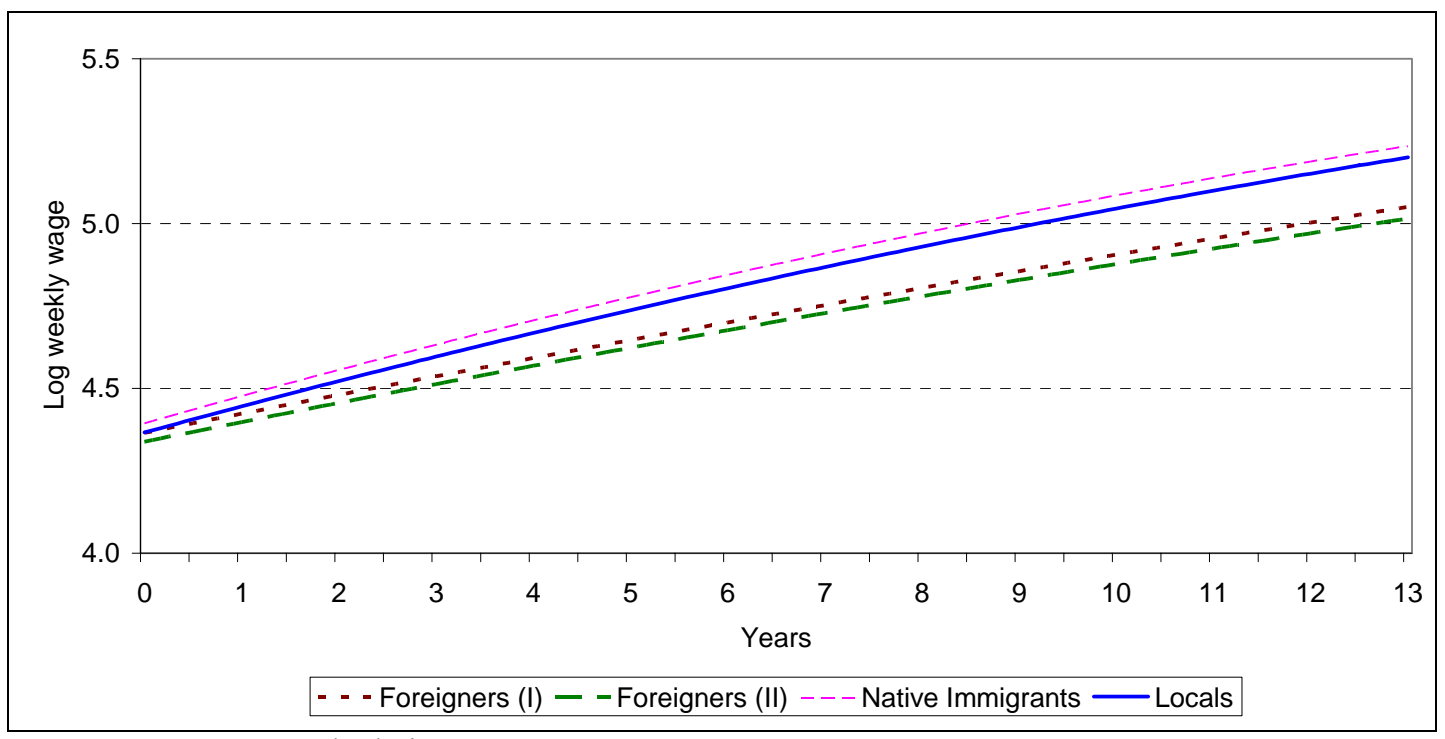

Source: WHIP, own calculations. 
Figure 5. Experience- log wage profiles for foreigners by main national groups and locals, males aged 18-45.

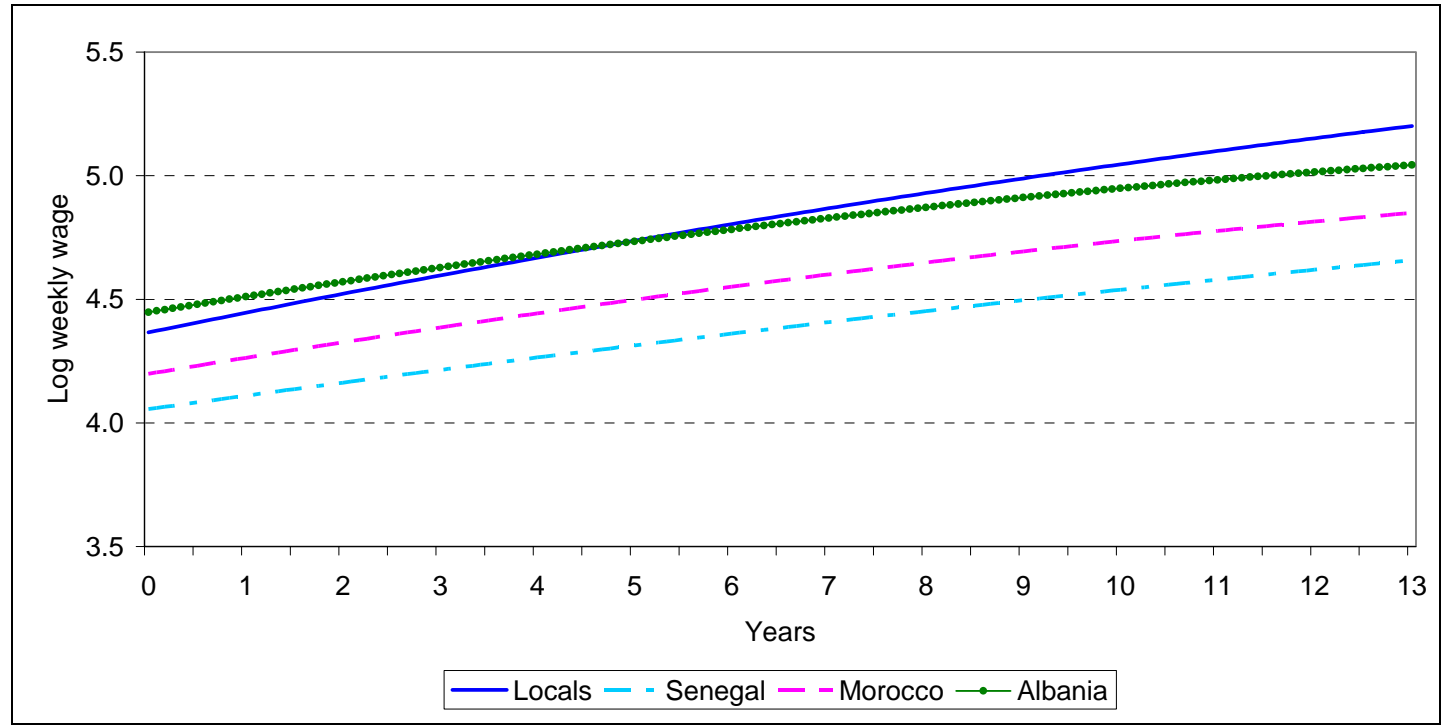

Source: WHIP, own calculations.

Figure 6. Experience- log wage profiles for foreigners, native immigrants and locals, males aged 18-45 entrants in 1991 and 1992.

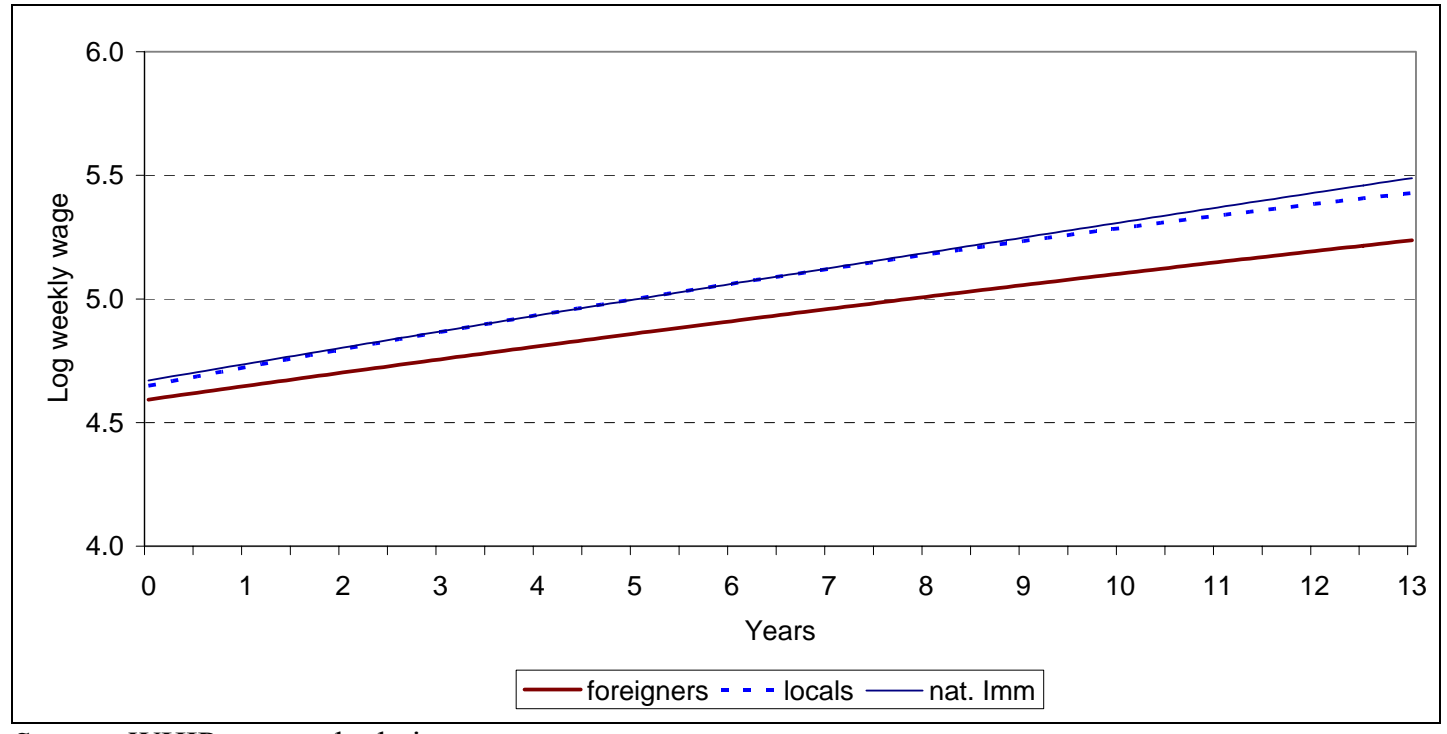

Source: WHIP, own calculations. 
Figure 7. Experience- log wage profiles for foreigners, native immigrants and locals, males aged 18-45 entrants in 1991 and 1992 by wage level at entrance.

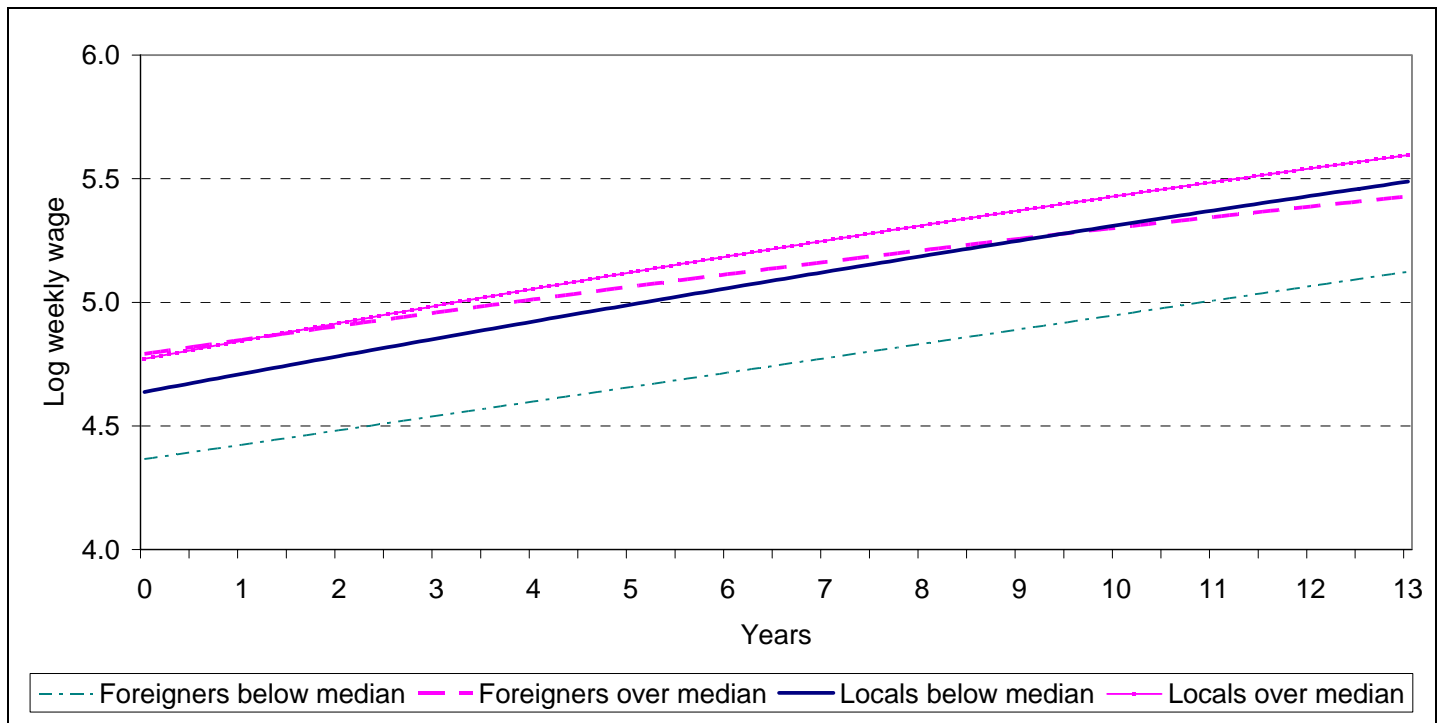

Source: WHIP, own calculations. 
Table 1. Descriptive statistics in 1990-2003 for foreign immigrants, native immigrants and locals.

\begin{tabular}{|c|c|c|c|c|c|c|}
\hline \multirow[b]{2}{*}{ Variable } & \multicolumn{2}{|c|}{ Foreign immigrants } & \multicolumn{2}{|c|}{ Native immigrants } & \multicolumn{2}{|c|}{ Locals } \\
\hline & Mean & (Std. Err.) & Mean & (Std. Err.) & Mean & (Std. Err.) \\
\hline Weekly wage & 291.8 & $(97.2)$ & 336.97 & $(0.67)$ & 317.35 & $(0.67)$ \\
\hline Age & 31.79 & (6.1) & 31.79 & (6.0) & 30.85 & (6.1) \\
\hline Age at entrance & 27.93 & (5.5) & 23.75 & (4.4) & 22.79 & (4.1) \\
\hline Months of employment & 42.88 & (38.4) & 85.14 & (57.4) & 90.01 & (58.4) \\
\hline Months out of employment & 10.27 & $(19.2)$ & 19.65 & (31.6) & 15.13 & (26.9) \\
\hline Blue collar & 0.93 & $(0.3)$ & 0.68 & $(0.5)$ & 0.64 & $(0.5)$ \\
\hline White collar & 0.03 & $(0.2)$ & 0.30 & $(0.5)$ & 0.32 & $(0.5)$ \\
\hline Apprentices & 0.03 & $(0.2)$ & 0.02 & $(0.1)$ & 0.04 & $(0.2)$ \\
\hline Atypical & 0.14 & $(0.3)$ & 0.11 & $(0.3)$ & 0.11 & $(0.3)$ \\
\hline Firm size $0 \_20$ & 0.58 & $(0.5)$ & 0.40 & $(0.5)$ & 0.45 & $(0.5)$ \\
\hline Firm size $20 \_200$ & 0.30 & $(0.5)$ & 0.29 & $(0.5)$ & 0.28 & $(0.4)$ \\
\hline Firm size $200 \_1000$ & 0.08 & $(0.3)$ & 0.15 & $(0.4)$ & 0.12 & (0.3) \\
\hline Firm size_over 1000 & 0.05 & $(0.2)$ & 0.17 & $(0.4)$ & 0.14 & $(0.3)$ \\
\hline North West & 0.39 & $(0.5)$ & 0.48 & $(0.5)$ & 0.31 & $(0.5)$ \\
\hline North East & 0.37 & $(0.5)$ & 0.25 & $(0.4)$ & 0.23 & $(0.4)$ \\
\hline Centre & 0.18 & $(0.4)$ & 0.21 & $(0.4)$ & 0.19 & $(0.4)$ \\
\hline South & 0.05 & $(0.2)$ & 0.06 & $(0.2)$ & 0.28 & $(0.4)$ \\
\hline Manufacturing & 0.52 & $(0.5)$ & 0.47 & $(0.5)$ & 0.50 & $(0.5)$ \\
\hline Construction & 0.21 & $(0.4)$ & 0.16 & $(0.4)$ & 0.13 & $(0.3)$ \\
\hline Services & 0.27 & $(0.4)$ & 0.38 & $(0.5)$ & 0.38 & $(0.5)$ \\
\hline Mediterranean Africa & 0.26 & $(0.4)$ & & & & \\
\hline Of which Moroccan & 0.14 & & & & & \\
\hline Africa other & 0.25 & $(0.4)$ & & & & \\
\hline Of which Senegalese & 0.22 & & & & & \\
\hline Latin America & 0.03 & $(0.2)$ & & & & \\
\hline Asia & 0.17 & $(0.4)$ & & & & \\
\hline East Europe & 0.29 & $(0.5)$ & & & & \\
\hline Of which Albanian & 0.17 & & & & & \\
\hline Avg. community size by region & $0.63 \%$ & $(0.6 \%)$ & $2.4 \%$ & $(1.6 \%)$ & & \\
\hline N. observations & 33622 & & 62484 & & 371481 & \\
\hline
\end{tabular}

Source: WHIP, own calculations. 
Table 2. Results of the selection equation.

\begin{tabular}{|c|c|c|c|c|}
\hline & \multicolumn{2}{|c|}{$\begin{array}{c}\text { Probit Random Effect } \\
\text { Model (II) }\end{array}$} & \multicolumn{2}{|c|}{$\begin{array}{c}\text { Weibull model } \\
\text { Model (III) }\end{array}$} \\
\hline Years of stay in Italy & $\begin{array}{r}0.797 \\
(0.021)\end{array}$ & $* * *$ & & \\
\hline Years of stay squared & $\begin{array}{r}-0.03 \\
(0.001)\end{array}$ & $* * *$ & & \\
\hline Real GDP per capita in origin country & $\begin{array}{r}0.0001 \\
(0.00002)\end{array}$ & $* * *$ & $\begin{array}{r}1.000 \\
(0.00001)\end{array}$ & $* * *$ \\
\hline Growth rate of Real GDP p.c. in orig. country & $\begin{array}{r}0.006 \\
(0.003)\end{array}$ & $*$ & $\begin{array}{r}1.081 \\
(0.010)\end{array}$ & $* * *$ \\
\hline Age at entry & $\begin{array}{r}0.044 \\
(0.005)\end{array}$ & $* * *$ & $\begin{array}{r}1.035 \\
(0.004)\end{array}$ & $* * *$ \\
\hline Share of irregular employment & $\begin{array}{r}0.017 \\
(0.005)\end{array}$ & $* * *$ & $\begin{array}{r}1.008 \\
(0.005)\end{array}$ & $*$ \\
\hline $\mathrm{p}$ (shape parameter) & & & $\begin{array}{r}1.846 \\
(0.026)\end{array}$ & \\
\hline $1 / \mathrm{p}$ & & & $\begin{array}{r}0.542 \\
(0.008)\end{array}$ & \\
\hline Predicted hazard rate (std. dev.) & & & $\begin{array}{r}5.15 \\
(10.1)\end{array}$ & \\
\hline N. obs & 36663 & & 8439 & \\
\hline Log likelihood & -9446.37 & & -4145.06 & \\
\hline Chi2 & 6223.71 & & 2495 & \\
\hline Prob $>$ chi 2 & 0.000 & & 0.000 & \\
\hline
\end{tabular}

Dependent variable: probability of leaving.

Further controls: firm size, sector and year of entry. Standard errors in parentheses. * Statistically significant at the .10 level; ** at the .05 level; *** at the 0.01 level.

Source: WHIP, own calculations. 
Table 3. Fixed effect estimates of log weekly wage in nominal terms, males aged 18-45.

\begin{tabular}{|c|c|c|c|c|c|c|c|c|}
\hline & \multicolumn{2}{|c|}{$\begin{array}{c}\text { Foreign immigrants } \\
\quad(\text { Correction }= \\
\text { Inv. Mills Ratio }) \\
\end{array}$} & \multicolumn{2}{|c|}{$\begin{array}{c}\text { Foreign immigrants } \\
(\text { Correction }= \\
\text { Hazard .Rate) }\end{array}$} & \multicolumn{2}{|c|}{ Native immigrants } & \multicolumn{2}{|l|}{ Locals } \\
\hline Intercept & $\begin{array}{r}4.425 \\
(0.253)\end{array}$ & $* * *$ & $\begin{array}{r}4.482 \\
(0.237)\end{array}$ & $* * *$ & $\begin{array}{r}4.498 \\
(0.132)\end{array}$ & $* * *$ & $\begin{array}{r}4.454 \\
(0.039)\end{array}$ & $* * *$ \\
\hline Age & $\begin{array}{r}0.032 \\
(0.009)\end{array}$ & $* * *$ & $\begin{array}{r}0.031 \\
(0.009)\end{array}$ & $* * *$ & $\begin{array}{r}0.046 \\
(0.008)\end{array}$ & $* * *$ & $\begin{array}{r}0.056 \\
(0.003)\end{array}$ & $* * *$ \\
\hline $\mathrm{Age}^{\wedge} 2$ & $\begin{array}{r}-0.00019 \\
(0.0001)\end{array}$ & $* * *$ & $\begin{array}{r}-0.00013 \\
(0.0001)\end{array}$ & * & $\begin{array}{r}-0.00022 \\
(0.00004)\end{array}$ & $* * *$ & $\begin{array}{r}-0.00026 \\
(0.00002)\end{array}$ & $* * *$ \\
\hline Months of employment & $\begin{array}{r}0.0023 \\
(0.001)\end{array}$ & $* * *$ & $\begin{array}{l}0.0023 \\
(0.001)\end{array}$ & $* * *$ & $\begin{array}{r}0.0031 \\
(0.001)\end{array}$ & $* * *$ & $\begin{array}{r}0.002 \\
(0.0002)\end{array}$ & $* * *$ \\
\hline Months of employment ${ }^{\wedge} 2$ & $\begin{array}{r}-0.000003 \\
(0.000001)\end{array}$ & $* * *$ & $\begin{array}{r}-0.000002 \\
(0.000001)\end{array}$ & $* * *$ & $\begin{array}{r}-0.00001 \\
(0.0000005)\end{array}$ & $* * *$ & $\begin{array}{r}-0.00001 \\
(0.0000002)\end{array}$ & $* * *$ \\
\hline Months out of employm. & $\begin{array}{r}0.0009 \\
(0.0007)\end{array}$ & & $\begin{array}{r}0.001 \\
(0.0007)\end{array}$ & & $\begin{array}{r}-0.0004 \\
(0.0006)\end{array}$ & & $\begin{array}{r}-0.001 \\
(0.0004)\end{array}$ & $* * *$ \\
\hline Log Value Added & $\begin{array}{r}0.070 \\
(0.022)\end{array}$ & $* * *$ & $\begin{array}{r}0.073 \\
(0.021)\end{array}$ & $* * *$ & $\begin{array}{r}0.055 \\
(0.011)\end{array}$ & $* * *$ & $\begin{array}{r}0.061 \\
(0.004)\end{array}$ & $* * *$ \\
\hline Reg. unemployment rate & $\begin{array}{r}0.002 \\
(0.003)\end{array}$ & & $\begin{array}{r}0.002 \\
(0.003)\end{array}$ & & $\begin{array}{l}-0.003 \\
(0.001)\end{array}$ & $* * *$ & $\begin{array}{r}-0.006 \\
(0.0003)\end{array}$ & $* * *$ \\
\hline Share of reg. for. employm. & $\begin{array}{r}0.256 \\
(1.280)\end{array}$ & & $\begin{array}{r}0.043 \\
(4.300)\end{array}$ & & $\begin{array}{r}-1.668 \\
(0.575)\end{array}$ & $* * *$ & & \\
\hline Share of reg. for. empl. ${ }^{\wedge} 2$ & $\begin{array}{r}0.016 \\
(1.600)\end{array}$ & & $\begin{array}{r}-0.032 \\
(0.320)\end{array}$ & & $\begin{array}{r}0.103 \\
(0.061)\end{array}$ & $*$ & & \\
\hline Correction for return migration & $\begin{array}{r}0.005 \\
(0.003)\end{array}$ & $*$ & $\begin{array}{r}0.032 \\
(0.007)\end{array}$ & $* * *$ & & & & \\
\hline $\mathrm{N}$ obs & 27,933 & & 27,933 & & 60,678 & & 359,527 & \\
\hline $\mathrm{F}$ & 119.00 & & 119.88 & & 591.88 & & 6031.63 & \\
\hline $\operatorname{corr}\left(u \_i, X b\right)=$ & -0.533 & & -0.5348 & & -0.3118 & & -0.4073 & \\
\hline Prob $>\mathrm{F} \quad=$ & 0.0000 & & 0.0000 & & 0.0000 & & 0.0000 & \\
\hline R-sq: within $=$ & 0.3673 & & 0.3680 & & 0.5296 & & 0.6079 & \\
\hline between $=$ & 0.0587 & & 0.0584 & & 0.1855 & & 0.2370 & \\
\hline overall $=$ & 0.1281 & & 0.1273 & & 0.2599 & & 0.3341 & \\
\hline
\end{tabular}

Dependent variable: log weekly wage.

Further controls: type of contract, firm size, sector, region and year dummies. Robust Standard errors in parentheses. * Statistically significant at the .10 level; ** at the .05 level; *** at the 0.01 level. Source: WHIP, own calculations. 
Table 4. Characteristics of foreign workers by origin. Average 1990-2003

\begin{tabular}{llll}
\hline & Senegal & Morocco & Albania \\
\hline Weekly Wage (€) & & & \\
Average months of employment & 278.7 & 267.7 & 273.1 \\
Average age & 52.97 & 44.81 & 34.29 \\
Blue collar (\%) & 33.50 & 31.03 & 30.59 \\
Firm size 0_20 (\%) & 0.99 & 0.93 & 0.92 \\
North East (\%) & 0.51 & 0.56 & 0.68 \\
Construction (\%) & 0.32 & 0.42 & 0.29 \\
Manufacturing (\%) & 0.07 & 0.19 & 0.43 \\
Share in 1990 (\%) & 0.73 & 0.55 & 0.37 \\
\hline Share in 2003 (\%) & 0.169 & 0.081 & 0.000 \\
\hline Source: WHI, $\%$ cam & 0.136 & 0.142 \\
\hline
\end{tabular}

Source: WHIP, own calculations.

Table 5. Fixed effect estimates of log weekly wage in nominal terms for males aged 18-45, main national groups.

\begin{tabular}{|c|c|c|c|c|c|c|c|c|}
\hline & \multicolumn{2}{|c|}{ Moroccans } & \multicolumn{2}{|c|}{ Senegalese } & \multicolumn{2}{|c|}{ Albaniens } & \multicolumn{2}{|l|}{ Locals } \\
\hline \multirow[t]{2}{*}{ Intercept } & 4.273 & $* * *$ & 4.081 & $* * *$ & 4.496 & $* * *$ & 4.454 & $* * *$ \\
\hline & $(0.407)$ & & $(0.523)$ & & $(0.633)$ & & $(0.039)$ & \\
\hline \multirow[t]{2}{*}{ Age } & 0.049 & $* * *$ & 0.035 & $* * *$ & 0.033 & $*$ & 0.056 & $* * *$ \\
\hline & $(0.007)$ & & $(0.006)$ & & $(0.019)$ & & $(0.003)$ & \\
\hline \multirow[t]{2}{*}{ Age $^{\wedge} 2$} & -0.00032 & $* * *$ & -0.00003 & & -0.00006 & & -0.00026 & $* * *$ \\
\hline & $(0.0001)$ & & $(0.0001)$ & & $(0.0002)$ & & $(0.0000)$ & \\
\hline \multirow[t]{2}{*}{ Months of employment } & 0.0014 & $* * *$ & 0.0016 & $* * *$ & 0.0027 & $* * *$ & 0.002 & $* * *$ \\
\hline & $(0.001)$ & & $(0.0003)$ & & $(0.001)$ & & $(0.0002)$ & \\
\hline \multirow[t]{2}{*}{ Months of employment $` 2$} & -0.00001 & $* *$ & -0.000004 & $* * *$ & -0.00001 & $* * *$ & -0.00001 & $* * *$ \\
\hline & $(0.000005)$ & & $(0.000001)$ & & $(0.000003)$ & & $(0.000000)$ & \\
\hline \multirow[t]{2}{*}{ Months out of employm. } & & & & & & & -0.001 & $* * *$ \\
\hline & & & & & & & $(0.0004)$ & \\
\hline \multirow[t]{2}{*}{ Log Value Added } & 0.106 & $* * *$ & 0.098 & $* *$ & 0.059 & & 0.061 & $* * *$ \\
\hline & $(0.044)$ & & $(0.047)$ & & $(0.049)$ & & $(0.004)$ & \\
\hline \multirow[t]{2}{*}{ Reg. unemployment rate } & 0.010 & & 0.005 & & 0.005 & & -0.006 & $* * *$ \\
\hline & $(0.006)$ & & $(0.008)$ & & $(0.006)$ & & $(0.0003)$ & \\
\hline \multirow[t]{2}{*}{ Share of reg. for. employm. } & 3.942 & $*$ & -4.115 & & 1.742 & & & \\
\hline & $(2.319)$ & & $(5.144)$ & & $(3.484)$ & & & \\
\hline \multirow[t]{2}{*}{ Corr. for return migration (Hazard rate) } & 0.074 & $* * *$ & 0.025 & $* *$ & 0.049 & $* * *$ & & \\
\hline & $(0.015)$ & & $(0.012)$ & & $(0.016)$ & & & \\
\hline $\mathrm{N}$ obs & 4386 & & 5997 & & 3904 & & 359527 & \\
\hline $\mathrm{F}$ & $3.31 \mathrm{E}+10$ & & 2625.88 & & 21.46 & & 6031.63 & \\
\hline $\operatorname{corr}\left(u \_i, X b\right)=$ & -0.7712 & & -0.5687 & & -0.7416 & & -0.4073 & \\
\hline Prob $>$ F & 0.0000 & & 0.0000 & & 0.0000 & & 0.0000 & \\
\hline R-sq: within $=$ & 0.4507 & & 0.4691 & & 0.3279 & & 0.6079 & \\
\hline between $=$ & 0.0535 & & 0.0438 & & 0.0757 & & 0.237 & \\
\hline overall $=$ & 0.1104 & & 0.1489 & & 0.0995 & & 0.3341 & \\
\hline
\end{tabular}

Dependent variable: $\log$ weekly wage.

Further controls: type of contract, firm size, sector, region and year dummies. Robust Standard errors in parentheses. * Statistically significant at the .10 level; ** at the .05 level; *** at the 0.01 level.

Source: WHIP, own calculations. 
Table 6. Log wage profiles with increasing experience in the labour market.

Entrants in 1991 and 1992

\begin{tabular}{lrrrrrrr}
\hline & \multicolumn{2}{c}{ Foreigners } & \multicolumn{2}{c}{ Native immigrants } & \multicolumn{2}{c}{ Locals } \\
& MEAN & (Std. err.) & MEAN & (Std. err.) & MEAN & (Std. err.) \\
\hline Average N obs & 3554 & & 4878 & & 27083 & \\
$\begin{array}{l}\text { Weekly wage in euros at entrance } \\
\text { Average weekly wage in euros in the 1991- }\end{array}$ & 213.5 & $(68.5)$ & 253.4 & $(121.2)$ & 226.9 & $(100.2)$ \\
$\begin{array}{l}\text { 2003 period } \\
\text { Age at entrance }\end{array}$ & 276.2 & $(102.6)$ & 351.4 & $(185.2)$ & 322.0 & $(154.3)$ \\
$\begin{array}{l}\text { Average number of months of employment } \\
\text { in the 1991-2003 period }\end{array}$ & 28.8 & $(5.8)$ & 27.6 & $(7.1)$ & 25.4 & $(6.6)$ \\
$\begin{array}{l}\text { Average number of months out of } \\
\text { employment in the 1991-2003 period }\end{array}$ & 54.0 & $(42.4)$ & 56.5 & $(43.0)$ & 61.0 & $(46.2)$ \\
& 14.0 & $(21.2)$ & 21.1 & $(28.3)$ & 16.0 & $(24.7)$ \\
\% Morocco & & & & & & \\
\% Senegal & 17.3 & & & & & \\
\% Albania & 25.9 & & & & & \\
\hline Source WHIP, & 3.8 & & & & & & \\
\hline
\end{tabular}

Source: WHIP, own calculations.

Table 7. Fixed effect estimates of log weekly wage in nominal terms for males aged 18-45, entrants in 1991 and 1992.

\begin{tabular}{|c|c|c|c|c|c|c|}
\hline & Foreig & ners & Native immigra & ints & Locals & \\
\hline Intercept & 4.843 & $* * *$ & 4.772 & $* * *$ & 4.731 & $* * *$ \\
\hline & $(0.177)$ & & $(0.341)$ & & $(0.126)$ & \\
\hline Age & 0.046 & $* * *$ & 0.045 & $* * *$ & 0.067 & $* * *$ \\
\hline & $(0.006)$ & & $(0.008)$ & & $(0.002)$ & \\
\hline $\operatorname{Age}^{\wedge} 2$ & -0.0005 & $* * *$ & -0.00031 & $* *$ & -0.00019 & $* * *$ \\
\hline & $(0.0001)$ & & $(0.0002)$ & & $(0.0001)$ & \\
\hline Months of employment & 0.0008 & $*$ & 0.0018 & $* * *$ & 0.0008 & $* * *$ \\
\hline & $(0.0005)$ & & $(0.0005)$ & & $(0.0002)$ & \\
\hline Months of employment ${ }^{\wedge} 2$ & 0.000003 & & 0.00001 & & -0.00001 & $* * *$ \\
\hline & $(0.000003)$ & & $(0.000008)$ & & $(0.000001)$ & \\
\hline Months out of employm. & & & & & -0.00135 & $* * *$ \\
\hline & & & & & $(0.0002)$ & \\
\hline Log VA & 0.057 & $* * *$ & 0.12 & $* * *$ & 0.035 & $* * *$ \\
\hline & $(0.018)$ & & $(0.036)$ & & $(0.014)$ & \\
\hline Reg. unemployment rate & 0.002 & & 0.007 & & -0.013 & $* * *$ \\
\hline & $(0.003)$ & & $(0.005)$ & & $(0.001)$ & \\
\hline Share of reg. for. employm. & -1.387 & & 0.537 & & & \\
\hline & $(1.387)$ & & $(1.074)$ & & & \\
\hline Corr. for return migr. (Hazard Rate) & 0.012 & $*$ & & & & \\
\hline & $(0.007)$ & & & & & \\
\hline $\mathrm{N}$ obs & 3554 & & 4878 & & 27083 & \\
\hline $\mathrm{F}$ & 58.88 & & 29.85 & & 434.10 & \\
\hline $\operatorname{corr}\left(u \_i, X b\right)=$ & -0.4074 & & -0.1836 & & -0.3654 & \\
\hline Prob $>\mathrm{F} \quad=$ & 0.0000 & & 0.0000 & & 0.0000 & \\
\hline R-sq: within $=$ & 0.4458 & & 0.5257 & & 0.5933 & \\
\hline between $=$ & 0.1222 & & 0.2206 & & 0.2178 & \\
\hline overall $=$ & 0.2239 & & 0.3041 & & 0.3371 & \\
\hline
\end{tabular}

Dependent variable: log weekly wage.

Further controls: type of contract, firm size, sector, region and year dummies. Robust Standard errors in parentheses. * Statistically significant at the .10 level; ** at the .05 level; *** at the 0.01 level. Source: WHIP, own calculations. 
Table 8. Fixed effect estimates of log weekly wage in nominal terms, males aged 18-45, blue-collar entrants in 1991 and 1992 by wage level at entrance.

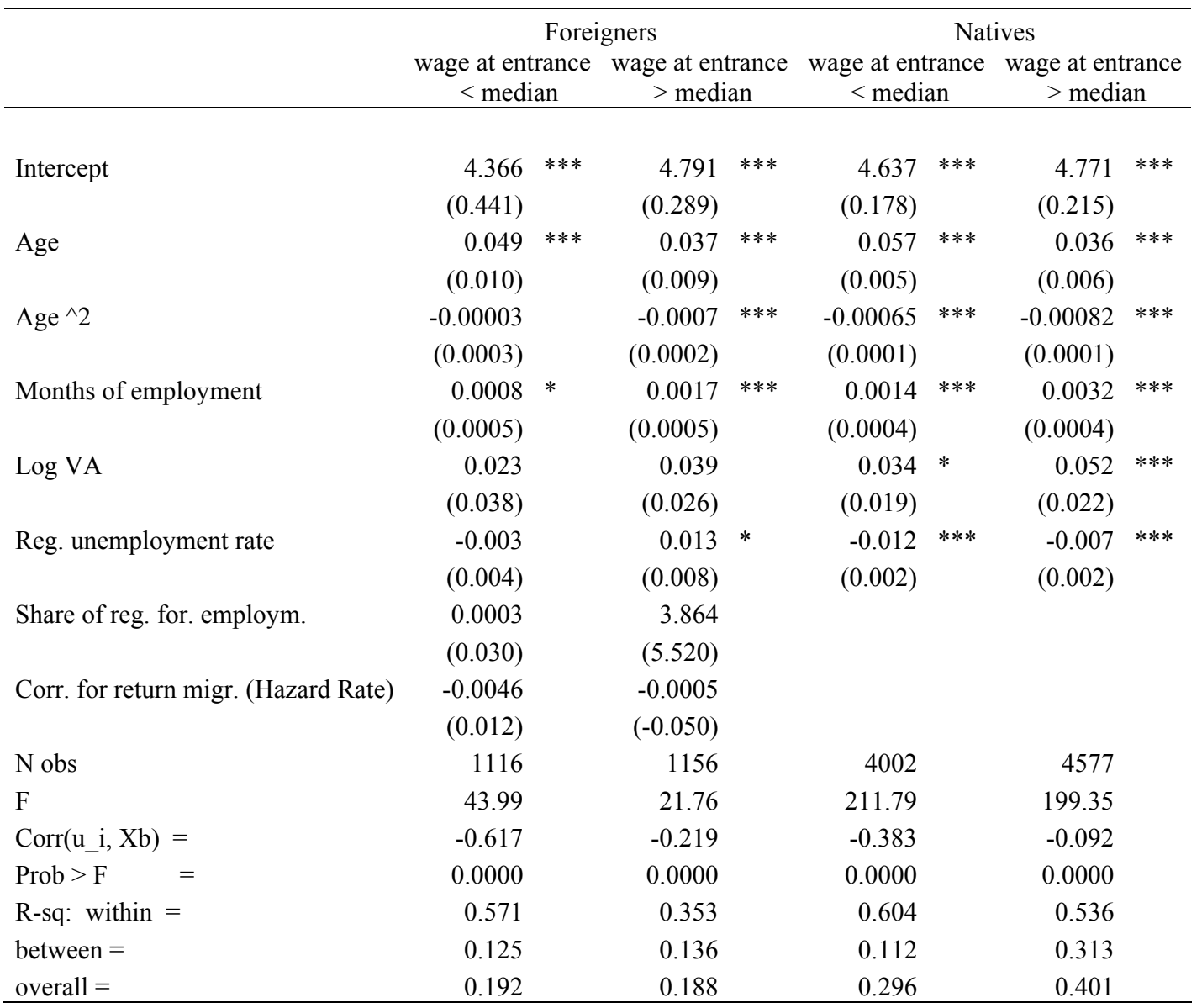

Dependent variable: log weekly wage.

Further controls: type of contract, firm size, sector, region and year dummies. Robust Standard errors in parentheses. * Statistically significant at the .10 level; ** at the .05 level; *** at the 0.01 level. Source: WHIP, own calculations. 